Journal of

Sedimentary

Research
Journal of Sedimentary Research, 2018, v. 88, 1-19

Research Article

DOI: http://dx.doi.org/10.2110/jsr.2018.4

\title{
PALEO-EOLIAN DYNAMICS IN THE ANDEAN PLATEAU: INFERENCES FROM SEDIMENTOLOGY OF FOSSIL AND MODERN DUNES
}

\author{
ROMINA LUCRECIA LÓPEZ STEINMETZ ${ }^{1,2}$ AND LORENA CECILIA LÓPEZ STEINMETZ ${ }^{3}$ \\ ${ }^{1}$ Instituto de Geología y Minería, Universidad Nacional de Jujuy, Avenida Bolivia 1661, Jujuy 4600, Argentina \\ ${ }^{2}$ Instituto de Ecorregiones Andinas (INECOA), Universidad Nacional de Jujuy, CONICET, S.S. de Jujuy 4600, Argentina \\ ${ }^{3}$ CONICET Jujuy, Ecuador 53, Jujuy 4600, Argentina \\ e-mail: lucrecialopezsteinmetz@hotmail.com
}

\begin{abstract}
The impressive eolian landscape of the Andean Plateau results from a combination of multiple factors controlling the formation of fossil and modern morphologies. We investigated fossil and modern eolian dunes set along the eastern border of the Plateau at ca. $22-23^{\circ} \mathrm{S}$. We applied sedimentology, statistics, and physical eolian models of sand transport in order to infer the characteristics of the eolian system during the past. Modern dunes are composed of medium sands, including more than $80 \%$ of quartz grains complemented by lithic fractions sourced predominantly from metasedimentary units, and a mean bulk-sediment density of $1611 \mathrm{~kg} / \mathrm{m}^{3}$. Fossil dunes are most likely Miocene in age, and are texturally similar to modern dunes. However, fossil sands are characterized by a mean density of $1209 \mathrm{~kg} /$ $\mathrm{m}^{3}$, which results from the prevalence of a lightweight, volcanic lithotype. Similar to the present day, the Miocene eolian system was characterized by wind from the northwest. Dune-building processes would have been associated with a mean wind regime of about $9 \%$ slower during the Miocene compared to modern conditions. Additionally, two main mechanisms of sediment supply were identified in the eolian system: a local, and long-term mechanism of sediment deflation over dry surfaces and stream channels; and a temporary, fossil process that fed the Miocene eolian system with volcanic-related sediments sourced from west of the basin.
\end{abstract}

\section{INTRODUCTION}

This article contributes to the little-documented eolian processes on the Andean Plateau and, more particularly, focuses on its less-addressed windrelated Miocene paleoclimate. This paper offers interesting information on this under-studied environment and shows the environmental continuity from the Miocene to present.

Global Cenozoic climate was characterized by the alternation of cold and warm periods. Before the Miocene, climate was globally cooler than today and ice-sheet expansion was generalized at the poles (e.g., Lear et al. 2008). Between 17 and 15 Ma there occurred a period of global warming known as the Mid-Miocene Climate Optimum (Flower and Kennett 1994). Later on, the middle Miocene involved a climatic transition towards cooler and drier conditions across much of the planet (e.g., Shevenell et al. 2008; Hamon et al. 2013). Global climate also fluctuated drastically during the Quaternary (e.g., Ehlers and Gibbard 2007; Maslin 2009; Rose 2010). For instance, major changes occurred during the late Pleistocene and the Pleistocene-Holocene transition (Raymo et al. 1997; Ehlers and Gibbard 2007). A number of hypotheses have been proposed to account for global Cenozoic climate changes: changes in land-sea distribution (e.g., Barron and Washington 1985), variations in ocean circulation due to changes in continental positions (e.g., Hamon et al. 2013), changes in continental topography (e.g., Garreaud 2009), the rate of weathering of silicate rocks accompanying the global escalation in orogenic uplift (e.g., Raymo et al. 1988), volcanic activity (e.g., Kelly and Sear 1984; Swingedouw et al. 2017), etc. Beyond the nature and number of converging factors that have caused climatic changes, the paleoclimate record shows that the Earth's climate is always changing.

In the Central Andes, and more particularly in the Puna Plateau (Fig. 1), the Eocene-Oligocene was characterized by a semiarid climate (Parrish et al. 1982; Hartley 2003; Alonso et al. 2006). Arid conditions similar to the modern arose in the Miocene. The middle to late Miocene of the Puna Plateau was additionally characterized by active mountain building (Gregory-Wodicki 2000, among others), the onset of widely distributed volcanic activity (e.g., Kay and Coira 2009), and the formation of thick evaporitic strata and giant salars (e.g., Alonso et al. 1991). In northern Puna, arid conditions would have been persistent during most of the Pleistocene (Abril and Amengual 1999). Since $150 \mathrm{kyr}$ BP environmental conditions changed with the occurrence of some cooler and more humid phases accompanied by glacial (Zipprich et al. 1999; Fritz et al. 2004; Fritz et al. 2007; Zech et al. 2009a, 2009b) and lacustrine (McGlue et al. 2013; López Steinmetz and Galli 2015) activity in the eastern border of northern Puna.

Paleo-environment studies in northern Puna have focused mainly on the hydrological aspect of the climate due to the abundance of lacustrine, evaporitic, glacial, and alluvial deposits and the existence of multiple techniques and proxies to assess paleohydrology (Sylvestre et al. 1999; Argollo and Mourguiart 2000; Fornari et al. 2001; Paduano et al. 2003; Tapia et al. 2003; Quade et al. 2008; Zech et al. 2009a, 2009b; Blard et al. 2011; Gayo et al. 2012; López Steinmetz and Galli 2015; and references therein). On the contrary, the eolian paleoenvironment has been little addressed, due mainly to only a few eolian units having been reported in 


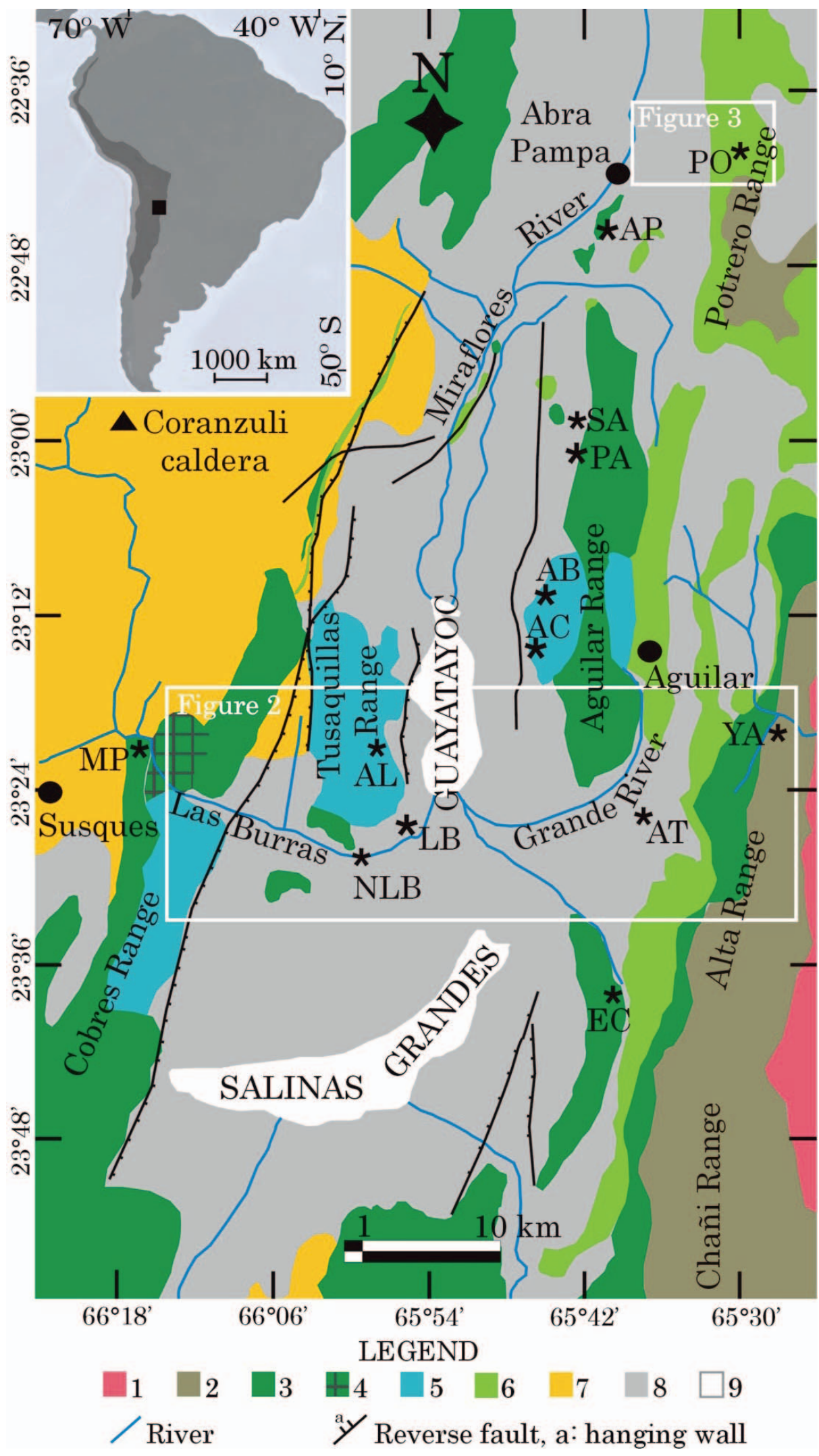

Fig. 1.-Simplified geologic map of the study area. Sampled sites are identified by black stars. Black circles indicate the location of major towns. 1, Puncoviscana Formation (Precambrian-Eocambrian); 2, Meson Group (upper Cambrian); 3 , Santa Victoria Group (lower to middle Ordovician); 4, peraluminous granite (middle to upper Ordovician); 5, alkaline granite (Jurassic-Cretaceous); 6, Salta Group (Cretaceous-middle Eocene); 7, ignimbrite (upper Miocene); 8 , alluvial deposits (upper Pleistocene-middle Holocene); 9 , playa lake and salar (upper Holocene). 
the Cenozoic record of the southern Central Andean region (Díaz and Malizzia 1983; Alonso 1986; Adelmann and Görler 1998; Kraemer et al. 1999; Voss 2002; Dávila and Astini 2003; Carrapa et al. 2005; del Papa et al. 2013a, 2013b; Galli et al. 2014). The only known feature of the regional paleo-wind activity is wind direction. The wind has remained most likely unidirectional for the past $2 \mathrm{Ma}$ (Greene 1995). Other aspects of the paleoeolian environment remain mostly unexplored on the Plateau. In this research we study modern and fossil dunes on the eastern border of the Plateau, between $22^{\circ} 36^{\prime}$ and $23^{\circ} 48^{\prime} \mathrm{S}$. The objective of our investigation was the characterization of the Miocene eolian environment, by assessing the three following variables of eolian processes and dune building: the wind direction, the wind speed, and sand provenance.

The high-altitude, arid, and windy climate of the Andean Plateau provides an extreme environment conducive to the formation of exceptional desert-eolian morphologies. For example, unusual gravel megaripples mantled by pumice and lithic clasts form in the southernmost Plateau (Milana 2009; de Silva 2010; Milana et al. 2010; de Silva et al. 2013), while impressive wind-formed ridges and ripples on ignimbrite bedrock can be observed on satellite imagery throughout the region (Greene 1995; Bailey et al. 2007; de Silva et al. 2010).

The eolian landscape of the Andean Plateau is complex and includes modern and fossil morphologies. Current eolian processes result from persistent wind from the northwest (Greene 1995; Inbar and Risso 2001; Bailey et al. 2007; de Silva et al. 2010). Wind velocity increases with elevation (de Silva et al. 2013), reaching exceptional gusts of $440 \mathrm{~km} / \mathrm{h}$ at $\sim 4000 \mathrm{~m}$ height in the southernmost Andean Plateau (Milana 2009)

Our investigation aims to obtain an approximation of the physical elements defining the Miocene wind-related climate. We first introduce the modern eolian system and the environmental characteristics of the study region. Then, we provide a detailed description of the studied modern and fossil dunes. The discussion section addresses the characterization of the paleo-eolian system based on a comparison between the modern and fossil dunes. The source area and the paleo-wind direction are assessed based on the lithological composition of sands and eolian sedimentary structures, such as cross beds and reactivation surfaces. The paleo-eolian dynamics are inferred by applying the physical eolian models of Bagnold (1954) and Zingg (1953) to grain sizes characterizing the fossil dunes in order to better understand the intensity of past wind conditions on the plateau.

\section{GEOLOGICAL AND ENVIRONMETNAL SETTING OF THE STUDY AREA}

The eolian dunes considered in this study are located at $3400 \mathrm{~m}$ above sea level (asl) and found throughout an area comprising the eastern border of the Andean Plateau, between $22^{\circ} 36^{\prime}$ and $23^{\circ} 48^{\prime} \mathrm{S}$ (Fig. 1). The regional desert environment is largely influenced by elevation (Garreaud 2009), with strong diurnal temperature fluctuations (frequently exceeding $18^{\circ} \mathrm{C}$ ) and high rates of evaporation. The hydrological year is characterized by a short rainy season, with an average of $\sim 350 \mathrm{~mm} / \mathrm{yr}$ of precipitation, concentrated during the summer. These summer rains are brought by easterly winds from the Atlantic. The rainy season is followed by a long, dry period extending from autumn to spring. Surface water resources are scarce, soils are skeletal, and bajadas (alluvial piedmonts) are sparsely covered by shrub steppe vegetation. Predominant vegetation includes halophytes and grasses that typically reach only a few centimeter in height. During the dry period, persistent winds blow transversally to the cordillera, on elevated areas of the Central Andes. Wind is locally called Viento Norte, or more regionally known as Viento Zonda. This dry wind is driven by the foehn effect from the Pacific Ocean. The eolian dynamics are especially active during the critical dry period between July and October. The predominant wind direction is from the NW, and the average wind velocity is $24 \mathrm{~km} / \mathrm{h}$ with gusts of up to $80 \mathrm{~km} / \mathrm{h}$ (Bianchi 1981; Buitrago and Larran 1994; Igarzábal and Rivelli 1996).
The study area lies in an endorheic basin delimited to the east and west by $\mathrm{N}-\mathrm{S}$ - elongated ranges. These ranges expose the basement, which consists of metasedimentary units (the Precambrian-Eocambrian Puncoviscana Formation, the upper Cambrian Meson Group, and the lower to middle Ordovician Santa Victoria Group; Turner 1960a, 1960b), middle to upper Ordovician peraluminous plutonic complexes, and Jurassic to Cretaceous alkaline granites (Méndez et al. 1973; Zapettini 1989; Coira et al. 1999; Cristiani et al. 1999; Kirschbaum et al. 2006). The eastern side of the basin also has outcrops of red and yellow sedimentary sequences, including the Pirgua, Balbuena, and Santa Bárbara subgroups (Salta Group, Cretaceous-middle Eocene; Turner 1959). The western border of the study area is largely covered by an upper Miocene ignimbrite platform (Seggiaro 1994).

Quaternary alluvial conglomerates extend from the foot of the ranges and prograde towards the flat areas, where fine-grained facies interdigitate with alluvial-plain sediments and evaporites (López Steinmetz 2013; López Steinmetz and Galli 2015). The low-lying areas are occupied by salt pans, an alluvial plain, and are covered by more than $500 \mathrm{~km}^{2}$ of Holocene to modern dunefields (Igarzábal and Rivelli 1996; López Steinmetz and Galli 2015). These eolian deposits include up to 1-m-high nebkas, conical accumulations up to 3 meters high; and isolated barchan dunes that are up to $7 \mathrm{~m}$ high (Igarzábal and Rivelli 1996). Towards the north, near the town of Abra Pampa, dunefields extend over $40 \mathrm{~km}^{2}$ (Fig. 1).

The fossil eolian deposits we describe in this contribution have not been previously studied. Fossil eolian units reported through the southern Central Andean region seem to indicate that eolian Cenozoic deposition started in the Miocene. For example, in the southernmost plateau, the Chacras Formation from the Salar de Antofalla Basin (ca. $26^{\circ} \mathrm{S}$ ) includes eolian dunes up to $120 \mathrm{~m}$ thick (Adelman and Görler 1998; Kraemer et al. 1999; Voss 2002; Carrapa et al. 2005). Biotites from intercalated tuffs in these fossil dunes yielded an average $\mathrm{K} / \mathrm{Ar}$ age of $22.50 \pm 0.60 \mathrm{Ma}$ (Kraemer et al. 1999). Some minor eolian facies are also present in the lower to middle Miocene Pozuelos Formation from the Salar de Pastos

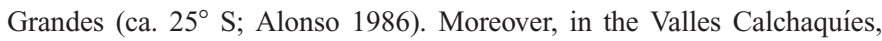
along the eastern border of the southern Plateau (ca. $26^{\circ} \mathrm{S}$ ), deposits, up to $600 \mathrm{~m}$ thick, formed by white, well-sorted sands in the upper sequence of the Angastaco Member (Quebrada de los Colorados Formation) represent deposition in eolian dunefields (Díaz and Malizzia 1983; del Papa et al. 2013a, 2013b; Galli et al. 2014). Zircons from a tuff intercalated at the base of these eolian deposits yield an average ${ }^{206} \mathrm{Ar}{ }^{238} \mathrm{Ar}$ age of $21 \pm 0.80$ Ma (del Papa et al. 2013a). Towards the southern edge of the Central Andes, the lower to middle Miocene Santo Domingo Member (El Durazno Formation) in the Famatina area (ca. $27^{\circ} \mathrm{S}$ ) is also typically characterized by eolian deposits (Dávila and Astini 2003).

\section{METHODS}

\section{Sampling and Analysis of Samples}

Modern dunes were sampled at the nine active eolian sites that exist in the study area. Three samples were taken from each site between 0.30 and $0.60 \mathrm{~m}$ depth. The sampled sites are: the Guayatayoc-Salinas Grandes dunefield (samples LB), the Alta Range climbing dunes (AT), the Yacoraite falling dunes (YA), and the El Colorado (EC), Agua de Castilla (AC), Abra Laite (AB), Sayate (SA), Abra Pampa (AP), and Potrero dunes (PO; Fig. 1, Table 1). Three fossil eolian deposits were sampled and described at a scale of 1:100: Alfarcito (AF), Mal Paso (MP), and Pabellón (PA; Fig. 1, Table 1). Three alluvial (non-eolian) samples were collected in the stream channel of the Las Burras River (sample NLB, Fig. 1). These alluvial samples were collected in order to characterize the texture of available sediments at the source area of active dunes.

The textures of samples were determined with the Udden scale using the standard sieve method. The sedimentary textures are presented in Table 2, 
TABLE 1.-Geographic data of the studied modern and fossil eolian deposits.

\begin{tabular}{|c|c|c|c|}
\hline & SITE & SAMPLE & LOCATION \\
\hline \multirow[t]{17}{*}{$\begin{array}{l}\text { Modern eolian } \\
\text { deposits }\end{array}$} & $\begin{array}{l}\text { Guayatayoc-Salinas } \\
\text { Grandes }\end{array}$ & $\mathrm{LBa}$ & $\begin{array}{l}23^{\circ} 29^{\prime} 42.32^{\prime \prime} \mathrm{S} \\
65^{\circ} 59^{\prime} 53.50^{\prime \prime} \mathrm{W}\end{array}$ \\
\hline & & $\mathrm{LBb}$ & $\begin{array}{l}23^{\circ} 27^{\prime} 30.65^{\prime \prime} \mathrm{S} \\
66^{\circ} 0^{\prime} 19.24^{\prime \prime} \mathrm{W}\end{array}$ \\
\hline & & $\mathrm{LBc}$ & $\begin{array}{l}23^{\circ} 26^{\prime} 37.39^{\prime \prime} \mathrm{S} \\
65^{\circ} 59^{\prime} 33.17^{\prime \prime} \mathrm{W}\end{array}$ \\
\hline & Alta Range & $\mathrm{ATa}$ & $\begin{array}{l}23^{\circ} 23^{\prime} 22.20^{\prime \prime} \mathrm{S} \\
65^{\circ} 41^{\prime} 38.05^{\prime \prime} \mathrm{W}\end{array}$ \\
\hline & & $\mathrm{ATb}$ & $\begin{array}{l}23^{\circ} 21^{\prime} 40.34^{\prime \prime} \mathrm{S} \\
65^{\circ} 39^{\prime} 53.45^{\prime \prime} \mathrm{W}\end{array}$ \\
\hline & & ATc & $\begin{array}{l}23^{\circ} 23^{\prime} 54.05^{\prime \prime} \mathrm{S} \\
65^{\circ} 37^{\prime} 10.10^{\prime \prime} \mathrm{W}\end{array}$ \\
\hline & Yacoraite & YA & $\begin{array}{l}23^{\circ} 19^{\prime} 16.38^{\prime \prime} \mathrm{S} \\
65^{\circ} 31^{\prime} 7.24^{\prime \prime} \mathrm{W}\end{array}$ \\
\hline & El Colorado & $\mathrm{ECa}$ & $\begin{array}{l}23^{\circ} 38^{\prime} 25.82^{\prime \prime} \mathrm{S} \\
65^{\circ} 40^{\prime} 44.03^{\prime \prime} \mathrm{W}\end{array}$ \\
\hline & & $\mathrm{ECb}$ & $\begin{array}{l}23^{\circ} 35^{\prime} 53.60^{\prime \prime} \mathrm{S} \\
65^{\circ} 43^{\prime} 1.54^{\prime \prime} \mathrm{W}\end{array}$ \\
\hline & & $\mathrm{ECc}$ & $\begin{array}{l}23^{\circ} 33^{\prime} 12.32^{\prime \prime} \mathrm{S} \\
65^{\circ} 44^{\prime} 2.26^{\prime \prime} \mathrm{W}\end{array}$ \\
\hline & Agua de Castilla & $\mathrm{AC}$ & $\begin{array}{l}23^{\circ} 13^{\prime} 59.25^{\prime \prime} \mathrm{S} \\
65^{\circ} 48^{\prime} 29.78^{\prime \prime} \mathrm{W}\end{array}$ \\
\hline & Abra Laite & $\mathrm{ABa}$ & $\begin{array}{l}23^{\circ} 10^{\prime} 2.79^{\prime \prime} \mathrm{S} \\
65^{\circ} 47^{\prime} 52.61^{\prime \prime} \mathrm{W}\end{array}$ \\
\hline & & $\mathrm{ABb}$ & $\begin{array}{l}23^{\circ} 10^{\prime} 23.80^{\prime \prime} \mathrm{S} \\
65^{\circ} 47^{\prime} 48.32^{\prime \prime} \mathrm{W}\end{array}$ \\
\hline & Sayate & SA & $\begin{array}{l}22^{\circ} 59^{\prime} 23.49^{\prime \prime} \mathrm{S} \\
65^{\circ} 45^{\prime} 28.29^{\prime \prime} \mathrm{W}\end{array}$ \\
\hline & Abra Pampa & $\mathrm{AP}$ & $\begin{array}{l}22^{\circ} 46^{\prime} 5.76^{\prime \prime} \mathrm{S} \\
65^{\circ} 43^{\prime} 12.53^{\prime \prime} \mathrm{W}\end{array}$ \\
\hline & Potrero & $\mathrm{POa}$ & $\begin{array}{l}22^{\circ} 40^{\prime} 51.94^{\prime \prime} \mathrm{S} \\
65^{\circ} 34^{\prime} 25.61^{\prime \prime} \mathrm{W}\end{array}$ \\
\hline & & $\mathrm{POb}$ & $\begin{array}{l}22^{\circ} 41^{\prime} 35.52^{\prime \prime} \mathrm{S} \\
65^{\circ} 32^{\prime} 25.46^{\prime \prime} \mathrm{W}\end{array}$ \\
\hline \multirow[t]{3}{*}{$\begin{array}{l}\text { Fossil eolian } \\
\text { deposits }\end{array}$} & Alfarcito fossil dunes & $\begin{array}{l}\mathrm{ALa} \\
\mathrm{ALb}\end{array}$ & $\begin{array}{l}23^{\circ} 19^{\prime} 44.9^{\prime \prime} \mathrm{S} \\
65^{\circ} 58^{\prime} 50.9^{\prime \prime} \mathrm{W}\end{array}$ \\
\hline & Mal Paso fossil dunes & $\begin{array}{l}\mathrm{MPa} \\
\mathrm{MPb} \\
\mathrm{MPc}\end{array}$ & $\begin{array}{lll}23^{\circ} & 25^{\prime} & 36.1^{\prime \prime} \mathrm{S} \\
66^{\circ} & 16^{\prime} & 12.3^{\prime \prime} \mathrm{W}\end{array}$ \\
\hline & Pabellón fossil dunes & $\begin{array}{l}\text { PAa } \\
\text { PAb }\end{array}$ & $\begin{array}{l}23^{\circ} 01^{\prime} 29.2^{\prime \prime} \mathrm{S} \\
65^{\circ} 44^{\prime} 11.7^{\prime \prime} \mathrm{W}\end{array}$ \\
\hline
\end{tabular}

which summarizes the textural average of all collected samples for each sampling location. For the determination of lithological compositions we counted 300 grains in the modal fraction of samples (Table 3). Further observations and photomicrographs were obtained under a petrographic microscope.

The bulk sediment density of each sample was established by a gravimetric protocol that considered the mean weight of $1000 \mathrm{~cm}^{3}, 500$ $\mathrm{cm}^{3}$, and $250 \mathrm{~cm}^{3}$ of sediments. The volume of sediments was obtained by adding the sediment sample in a test tube containing $1 \mathrm{~L}$ of water until obtaining 2000,1500 , and $1250 \mathrm{~cm}^{3}$, respectively. Sediment weights were then obtained by subtracting the weight of the test tube and water.

Spatial arrangements of sedimentary structures in fossil dunes, including reactivation surfaces and cross-bedding directions, were measured in order to infer the predominant paleo-wind direction (Table 4). The values of modern wind speed are based on surface data collected at the meteorological station at Abra Pampa, $3400 \mathrm{~m}$ asl, and summarized by Bianchi (1981), Bianchi and Yáñez (1992), Buitrago and Larran (1994), and Bianchi and Yáñez (2005).

\section{Physical Models of the Eolian Transport}

The wind shear velocity $(u *)$, the critical wind shear velocity $\left(u_{c}\right)$, and the wind velocity $\left(W_{(z)}\right)$ are used to estimate the wind paleo-dynamics (Table 6). The parameters $u_{*}, u_{*_{c}}$, and $W_{(z)}$ were calculated based on models proposed by Bagnold (1941, 1954) and Zingg (1953).

Eolian erosion begins when the wind shear velocity $\left(u_{*}\right)$ exceeds the movement threshold of the particles lying on the substrate surface. Shear velocity is exerted when turbulence increases and wind velocity increases. The more the wind shear velocity fluctuates, the more often grain motion occurs. The threshold value of the wind shear velocity was obtained from the formula proposed by Bagnold (1954):

$$
u_{* c}=A \sqrt{\left\{\left[\left(\rho_{s}-\rho_{a}\right) / \rho_{a}\right] g D\right\}}
$$

where $u_{*_{c}}$ represents the critical wind shear velocity when erosion begins, $\rho_{s}$ corresponds to the density for dry sediments, and $\rho_{a}$ is the air density. The considered air density value is $0.87 \mathrm{~kg} / \mathrm{m}^{3}$ according to the altitude (3400-3500 m). $g$ represents the acceleration due to gravity. $A$ is an experimental parameter, $A=0.1 . D$ is the particle size.

Particle movement occurs when dry sediments are exposed to wind and the flow reaches the velocity threshold. As movement begins, all lines of the wind velocity gradient converge at a focal point $\left(W^{\prime}, Z^{\prime}\right)$. Zingg (1953) proposed a link between the coordinates of the focal point and the sediment grain size:

$$
\begin{gathered}
W^{\prime}=894 D \\
Z^{\prime}=10 D \\
Z_{0}=0.081 \log (D / 0.18)
\end{gathered}
$$

During eolian transport, the wind velocity gradient can be obtained from the expression,

$$
W_{(z)} / u_{*}=1 / k \ln \left(Z / Z^{\prime}\right)+W^{\prime}
$$

where $u_{*}$ is the wind shear velocity, $W_{(z)}$ is the wind-velocity value at height $z$ above the boundary surface, and $k$ is the von Kármán parameter (von Kármán 1934; Sherman et al. 2013).

\section{Statistical Analysis}

We have evaluated the fossil and modern eolian environments using statistical analysis and data tests (Table 5). The parameters of the eolian dynamics (Table 6) were calculated considering: 1) the statistically representative sediment texture (the diameter $D$ refers to the lower limit on grain size in the mean fraction) and 2) the coarsest grain sizes, where the diameter $D_{\max }$ represents the coarsest grain size in samples.

The textural statistical analysis was undertaken with the premise that deposits represent the corresponding modern and fossil eolian dynamics. For textural statistical analysis we consider the mean $(M)$, and the variability of $M$, that was characterized by the standard deviation $(s)$. We also inform two other measures of central tendency: mode $(M o)$ and median $(M d)$ (Table 5). The statistical significance considers differences between means of independent samples. For calculation, data were grouped into two sets (a modern group and a fossil group) of 20 textural classes with $i=0.08 \mathrm{~mm}$ ( $i$ : amplitude of each class). Considered textures were between $0.01 \mathrm{~mm}$ (the apparent lower limit for the smaller textural class) and $1.68 \mathrm{~mm}$ (the apparent upper limit of the largest textural class).

The statistical analysis of density $(\rho)$ included the determination of the modern and fossil mean (i.e., the mean density of the modern eolian sands 
TABLE 2.-Textural analyses of sampled sediments.

\begin{tabular}{|c|c|c|c|c|c|c|c|c|c|c|c|c|c|c|c|c|c|c|c|c|c|c|}
\hline \multirow[b]{2}{*}{$\mathrm{mm}$} & \multicolumn{22}{|c|}{$\%$} \\
\hline & $\mathrm{LBa}$ & $\mathrm{LBb}$ & $\mathrm{LBc}$ & $\mathrm{AT}$ & YA & $\mathrm{ECa}$ & $\mathrm{ECb}$ & $\mathrm{ECc}$ & $\mathrm{AC}$ & $\mathrm{ABa}$ & $\mathrm{ABb}$ & SA & $\mathrm{AP}$ & $\mathrm{POa}$ & $\mathrm{POb}$ & $\mathrm{AL}$ & $\mathrm{MPa}$ & $\mathrm{MPb}$ & MPc & PAa & $\mathrm{PAb}$ & NLB \\
\hline 25.00 & - & - & - & - & - & - & - & - & - & - & - & - & - & - & - & - & - & - & - & - & - & 1.8 \\
\hline 18.75 & - & - & - & - & - & - & - & - & - & - & - & - & - & - & - & - & - & - & - & - & - & 7.2 \\
\hline 12.50 & - & - & - & - & - & - & - & - & - & - & - & - & - & - & - & - & - & - & - & - & - & 16.6 \\
\hline 4.76 & - & - & - & - & - & - & - & - & - & - & - & - & - & - & - & - & - & - & - & - & - & 14.1 \\
\hline 4.00 & - & - & - & - & - & - & - & - & - & - & - & - & - & - & - & - & - & - & - & - & - & 10.4 \\
\hline 2.83 & - & - & - & - & - & - & - & - & - & - & - & - & - & - & - & - & - & - & - & - & - & 4.9 \\
\hline 2.00 & - & - & - & - & - & - & - & - & - & - & - & - & - & - & - & - & - & - & - & - & - & 2.3 \\
\hline 1.68 & - & - & - & - & - & - & - & - & - & - & 1.0 & - & - & - & - & - & 0.5 & - & - & - & - & 1.8 \\
\hline 1.00 & 2.0 & 9.3 & 20.5 & 1.0 & - & - & - & 2.3 & - & 1.0 & 1.0 & - & - & - & - & - & 2.5 & 3.0 & 2.0 & - & 1.0 & 1.6 \\
\hline 0.71 & 32.2 & 62.4 & 60.8 & 1.0 & - & - & - & 10.8 & & 1.0 & 1.0 & - & - & - & - & 8.2 & 4.0 & 3.0 & 3.0 & - & 1.0 & 1.6 \\
\hline 0.50 & 11.7 & 18.6 & 9.1 & 1.0 & - & - & - & 32.7 & 0.0 & 1.0 & 1.0 & - & - & - & - & 25.5 & 16.0 & 4.0 & 4.0 & 3.1 & 28.0 & 3.7 \\
\hline 0.42 & 9.8 & 4.0 & 4.4 & 7.4 & 7.5 & 5.5 & 5.5 & 16.3 & 7.4 & 2.0 & 2.0 & 2.8 & 2.8 & 5.5 & 7.5 & 20.6 & 20.0 & 6.0 & 8.0 & 34.0 & 40.0 & 4.4 \\
\hline 0.25 & 9.8 & 5.3 & 1.3 & 27.7 & 60.2 & 41.5 & 41.5 & 14.4 & 27.7 & 10.0 & 34.0 & 29.1 & 29.1 & 41.5 & 60.0 & 22.6 & 26.0 & 14.0 & 12.0 & 48.4 & 20.0 & 6.6 \\
\hline 0.18 & 14.7 & - & 2.7 & 40.1 & 29.1 & 34.2 & 34.2 & 10.3 & 40.1 & 34.0 & 30.0 & 50.3 & 50.3 & 34.2 & 29.1 & 14.1 & 22.0 & 24.0 & 24.0 & 9.0 & 3.0 & 9.3 \\
\hline 0.12 & 11.8 & - & - & 19.4 & 2.6 & 10.7 & 10.7 & 6.2 & 19.4 & 40.0 & 24.0 & 13.1 & 13.1 & 10.7 & 2.6 & 6.5 & 4.0 & 32.0 & 30.0 & 2.4 & 2.0 & 6.1 \\
\hline 0.09 & 3.3 & - & - & 1.5 & - & 3.5 & 3.5 & 2.7 & 4.5 & 4.0 & 2.0 & 4.7 & 4.7 & 3.5 & - & 0.4 & 2.0 & 6.0 & 8.0 & 3.0 & 1.0 & 2.3 \\
\hline 0.06 & 3.64 & - & - & - & - & 2.9 & 2.9 & 2.1 & - & 3.0 & 1.0 & - & - & 2.9 & - & - & 2.0 & 4.0 & 4.0 & - & 1.0 & 2.6 \\
\hline 0.03 & - & - & - & - & - & - & - & 2.1 & - & 4.0 & 1.0 & - & - & - & - & - & 1.0 & 2.0 & 3.0 & - & 1.0 & 1.9 \\
\hline$<0.03$ & - & - & - & - & - & - & - & - & - & - & - & - & - & - & - & - & - & - & - & - & - & 0.5 \\
\hline Total \% & 100.0 & 99.7 & 98.9 & 99.2 & 99.3 & 98.4 & 98.4 & 99.9 & 99.2 & 100.0 & 98.0 & 99.9 & 99.9 & 98.4 & 99.3 & 97.9 & 100.0 & 98.0 & 98.0 & 99.9 & 98.0 & 99.7 \\
\hline Error \% & 0.0 & 0.3 & 1.1 & 0.8 & 0.7 & 1.6 & 1.6 & 0.1 & 0.8 & 0.0 & 2.0 & 0.1 & 0.1 & 1.6 & 0.7 & 2.1 & 0.0 & 2.0 & 2.0 & 0.1 & 2.0 & 0.3 \\
\hline
\end{tabular}

and the mean density of fossil eolian sands). These modern and fossil mean densities were employed in order to analyze the effect of the sediment nature in active and inactive eolian processes. The modern mean density was calculated by considering all samples from the nine active sand fields. The fossil mean density was obtained by considering all samples from the three fossil dunes. To calculate the modern mean density, 12 classes with $i$ $=10.09 \mathrm{~kg} / \mathrm{m}^{3}$ were considered, the apparent lower limit corresponded to the class containing the density $1560 \mathrm{~kg} / \mathrm{m}^{3}$ and the apparent upper limit reached $1681.19 \mathrm{~kg} / \mathrm{m}^{3}$. For fossil deposits, 12 classes were considered with $i=42.59 \mathrm{~kg} / \mathrm{m}^{3}$, the apparent lower limit corresponds to the class containing the density $947 \mathrm{~kg} / \mathrm{m}^{3}$ and the apparent upper limit reached $1458.19 \mathrm{~kg} / \mathrm{m}^{3}$.

The parametric hypothesis test was applied in order to establish the difference between the textural means of modern and fossil dunes. We considered a significance level $\alpha=0.01\left[t_{\mathrm{o}}(-0.33)<t_{\mathrm{c}}(2.33)\right]$, with $\mathrm{df}=$ $\mathrm{N}>30$ (df: degrees of freedom). The null hypothesis states that the observed difference between the modern and fossil textural means is null $\left(\mathrm{H}_{0}: \mathrm{M}_{1}=\mathrm{M}_{2}\right)$. The alternative hypothesis is that the textural mean of modern sands would be significantly lower than the fossil equivalent $\left(\mathrm{H}_{1}\right.$ : $\mathrm{M}_{1}<\mathrm{M}_{2}$ ).

In order to assess the validity of comparing the modern and the fossil eolian environments, and so as to establish the influence of wind dynamics and the sedimentological features of the source area in the eolian sedimentary textures, the Pearson correlation coefficient $(r)$ and the coefficient of linear determination $\left(R^{2}\right)$ were calculated with $\mathrm{n}=8$, [ $t_{\mathrm{o}}$ $\left.(7.63)>t_{\mathrm{c}}( \pm 3.25)\right]$ in modern dunes, $\left[t_{\mathrm{o}}(5.56)>t_{\mathrm{c}}( \pm 3.25)\right]$ in the fossil record, the significance level $\alpha=0.01$, with $\mathrm{df}=\mathrm{N}-2$, for the two-sided test (H1: $\rho \neq 0$ ). The determinations of $r$ and $R^{2}$ of the modern eolian environment are calculated using field-based data, and considering wind speed values collected at the meteorological station at Abra Pampa, integrated between 1961 and 1980, and reported by Bianchi (1981), Bianchi and Yáñez (1992), Buitrago and Larran (1994), and Bianchi and Yáñez (2005).

\section{Our Starting Hypothesis and the Model Reliability}

In wind dynamics, the energy threshold for initial sand movement is higher than that required for further transport. Since $u *$ does not affect sand movement until $u_{*_{c}}$ has led to the beginning of displacement, $u_{*_{c}}$ is the reference condition for the identification of flow features. Furthermore, according to Equation $1, u_{*_{c}}$ is closely linked to the textural characteristics of the sediment. Following Equation 1, coarser fractions require a higher $u *_{c}$ to start eolian transport than finer grains. Thus knowing $u_{*_{c}}$ for $D_{\max }$ constrains the maximum kinetic flow features of wind $\left(W_{z}\right)$ to begin the eolian transport of coarser fractions. Assuming that i) all movement is by saltation (not reptation), and ii) there is an unlimited supply of particles of all sizes; if the wind velocity had been lower, it would not have had enough energy to move grains with sizes $=D_{\max }$. Conversely, the existence, even transitory, of faster flow conditions would be represented in deposits by the presence of coarser textures than $D_{\max }$. According to data we are presenting in the results section of this article, the assumption of an unlimited supply of particles of all sizes is valid for the modern eolian system. However, in the fossil eolian system the pertinence of this assumption is uncertain. In the case of any kind of grain size restriction in the fossil eolian system, the employed methodology would offer a lower limit for the fossil $W_{\max }$. Additional constraints of past wind kinetics are addressed based on the textural mean of fossil deposits, which helps characterizing the $W_{\text {mean }}$ conditions.

Of the many options available for modeling wind erosion (see Livingstone et al. 2007; Sherman et al. 2013; among others), our methodological choice prioritized the predictive capacity of models when applied to the local settings. In order to test the predictive capacity, we compare the Bagnold (1954) and Zingg (1953) formulas and an alternative, more modern, wind-dynamics physical model. To compare models, we considered a $1.68 \mathrm{~mm}$ grain size, with a density of $1681 \mathrm{~kg} / \mathrm{m}^{3}$, and $z$ is taken as $2 \mathrm{~m}$. Following Equation $1, u *$ is $2.03 \mathrm{~km} / \mathrm{h}$ and Equation 5 yields a value of $W_{(z)}=78.31 \mathrm{~km} / \mathrm{h}$. On the other hand, when applying Namikas (2003), where $W_{(z)}=u *\left[2.5 \ln \left(Z / Z^{\prime}\right)\right]$ and $z^{\prime}=D / 30$, the obtained wind velocity $=53.23 \mathrm{~km} / \mathrm{h}$. We note that the equation of Namikas (2003) 
TABLE 3.-Lithological compositions of eolian samples.

\begin{tabular}{|c|c|c|c|c|c|c|c|c|c|}
\hline \multirow[b]{3}{*}{ Sample } & \multirow[b]{3}{*}{ total } & \multicolumn{8}{|c|}{ Counting Grains } \\
\hline & & \multicolumn{3}{|c|}{ Quartz } & \multicolumn{3}{|c|}{ Lithic } & \multicolumn{2}{|c|}{ Other } \\
\hline & & crystalline & white & reddish & red * & green, gray** & granite & biotite & glass shard \\
\hline \multirow[t]{2}{*}{ LBa } & 300 & 231 & 6 & 8 & 5 & 20 & 30 & - & - \\
\hline & $100 \%$ & 77.00 & 2.00 & 2.67 & 1.67 & 6.67 & 10.00 & - & - \\
\hline \multirow[t]{2}{*}{$\mathrm{LBb}$} & 300 & 225 & 2 & 7 & 5 & 17 & 44 & - & - \\
\hline & $100 \%$ & 75.00 & 0.67 & 2.33 & 1.67 & 5.67 & 14.67 & - & - \\
\hline \multirow[t]{2}{*}{$\mathrm{LBc}$} & 300 & 191 & 1 & 6 & 3 & 33 & 66 & - & - \\
\hline & $100 \%$ & 63.67 & 0.33 & 2.00 & 1.00 & 11.00 & 22.00 & - & - \\
\hline \multirow[t]{2}{*}{$\mathrm{ATa}$} & 300 & 284 & 14 & 1 & 1 & - & - & - & - \\
\hline & $100 \%$ & 94.67 & 4.67 & 0.33 & 0.33 & - & - & - & - \\
\hline \multirow[t]{2}{*}{$\mathrm{ATb}$} & 300 & 276 & 18 & 3 & 2 & 1 & - & - & - \\
\hline & $100 \%$ & 92.00 & 6.00 & 1.00 & 0.67 & 0.33 & - & - & - \\
\hline \multirow[t]{2}{*}{$\mathrm{ATc}$} & 300 & 300 & - & - & - & - & - & - & - \\
\hline & $100 \%$ & 100 & - & - & - & - & - & - & - \\
\hline \multirow{2}{*}{ YA } & 300 & 300 & - & - & - & - & - & - & - \\
\hline & $100 \%$ & 100 & - & - & - & - & - & - & - \\
\hline \multirow[t]{2}{*}{$\mathrm{ECa}$} & 300 & 271 & 19 & 10 & - & - & - & - & - \\
\hline & $100 \%$ & 90.33 & 6.33 & 3.33 & - & - & - & - & - \\
\hline \multirow{2}{*}{$\mathrm{ECb}$} & 300 & 269 & 9 & 12 & 10 & - & - & - & - \\
\hline & $100 \%$ & 89.67 & 3.00 & 4.00 & 3.33 & - & - & - & - \\
\hline \multirow[t]{2}{*}{$\mathrm{ECc}$} & 300 & 275 & 3 & 1 & 21 & - & - & - & - \\
\hline & $100 \%$ & 91.67 & 1.00 & 0.33 & 7.00 & - & - & - & - \\
\hline \multirow[t]{2}{*}{$\mathrm{AC}$} & 300 & 168 & 103 & - & - & 28 & 1 & - & - \\
\hline & $100 \%$ & 56.00 & 34.33 & - & - & 9.33 & 0.33 & - & - \\
\hline \multirow[t]{2}{*}{$\mathrm{ABa}$} & 300 & 188 & 94 & - & 1 & 17 & - & - & - \\
\hline & $100 \%$ & 62.67 & 31.33 & - & 0.33 & 5.67 & - & - & - \\
\hline \multirow[t]{2}{*}{$\mathrm{ABb}$} & 300 & 164 & 96 & 2 & - & 24 & 14 & - & - \\
\hline & $100 \%$ & 54.67 & 32.00 & 0.67 & - & 8.00 & 4.67 & - & - \\
\hline SA & 300 & 212 & 32 & - & - & 44 & 12 & - & - \\
\hline & $100 \%$ & 70.67 & 10.67 & - & - & 14.67 & 4.00 & - & - \\
\hline AP & 300 & 193 & 81 & 2 & 6 & 18 & - & - & - \\
\hline & $100 \%$ & 64.33 & 27.00 & 0.67 & 2.00 & 6.00 & - & - & - \\
\hline POa & 300 & 38 & 21 & 191 & 37 & 13 & - & - & - \\
\hline & $100 \%$ & 12.67 & 7.00 & 63.67 & 12.33 & 4.33 & - & - & - \\
\hline $\mathrm{POb}$ & 300 & 44 & 8 & 233 & 12 & 3 & - & - & - \\
\hline & $100 \%$ & 14.67 & 2.67 & 77.67 & 4.00 & 1.00 & - & - & - \\
\hline ALa & 300 & 77 & 30 & - & - & - & - & 155 & 38 \\
\hline & $100 \%$ & 25.67 & 10.00 & - & - & - & - & 51.67 & 12.67 \\
\hline ALb & 300 & 33 & 147 & - & - & - & 1 & 98 & 21 \\
\hline & $100 \%$ & 11.00 & 49.00 & - & - & - & 0.33 & 32.67 & 7.00 \\
\hline $\mathrm{MPa}$ & 300 & 74 & 100 & - & - & - & - & 33 & 93 \\
\hline & $100 \%$ & 24.67 & 33.33 & - & - & - & - & 11.00 & 31.00 \\
\hline $\mathrm{MPb}$ & 300 & 117 & 84 & - & - & - & - & 74 & 25 \\
\hline & $100 \%$ & 39.00 & 28.00 & - & - & - & - & 24.67 & 8.33 \\
\hline MPc & 300 & 83 & 109 & - & - & 1 & - & 69 & 38 \\
\hline & $100 \%$ & 27.67 & 36.33 & - & - & 0.33 & - & 23.00 & 12.67 \\
\hline PAa & 300 & 49 & 80 & - & - & 22 & 41 & 82 & 26 \\
\hline & $100 \%$ & 16.33 & 26.67 & - & - & 7.33 & 13.67 & 27.33 & 8.67 \\
\hline PAb & 300 & 53 & 104 & - & - & 37 & 24 & 64 & 18 \\
\hline & $100 \%$ & 17.67 & 34.67 & - & - & 12.33 & 8.00 & 21.33 & 6.00 \\
\hline
\end{tabular}

* Red lithics include red sandstones and mudstones (Pirgua Subgroup)

** green, gray lithics are shalestones and mudstones from the sedimentary basement (Santa Victoria Group)

underestimates the wind velocity by $25 \%$ (or, in other words, it overestimates wind capacity) relative to the result obtained by applying the model of Bagnold (1954). Accordingly, the equation of Namikas (2003) applied to a wind speed value of $W_{(z)}=80 \mathrm{~km} / \mathrm{h}$ (the modern maximum wind speed), predicts grain sizes larger than $1.68 \mathrm{~mm}$. Assuming that such particles are available, this estimate of wind speed implies that the modern conditions of maximum wind speed $\left(W_{(z)}=80 \mathrm{~km} /\right.$ h) should be represented by sediments coarser than those actually constituting modern dunes (e.g., samples LB: $D_{\max }=1 \mathrm{~mm}$ ).

It is remarkable that the model of Bagnold predicts that the wind velocities required to erode sediments similar to the modern eolian coarser fractions coincide with the current maximum wind speed recorded in the studied area $(80 \mathrm{~km} / \mathrm{h})$. This is in agreement with the premise stating that the maximum wind speed is texturally reflected in grain size. Therefore, 
TABLE 4.- Spatial arrangements of sedimentary structures in fossil dunes.

\begin{tabular}{|c|c|c|c|c|c|}
\hline & & \multicolumn{2}{|c|}{ Reactivation Surfaces } & \multicolumn{2}{|c|}{ Cross Beds } \\
\hline & & $\operatorname{dip}$ & dip direction & $\operatorname{dip}$ & dip direction \\
\hline \multirow[t]{21}{*}{$\mathrm{AL}$} & & $20^{\circ}$ & $135^{\circ}$ & $48^{\circ}$ & $136^{\circ}$ \\
\hline & & $12^{\circ}$ & $126^{\circ}$ & $45^{\circ}$ & $135^{\circ}$ \\
\hline & & $11^{\circ}$ & $134^{\circ}$ & $48^{\circ}$ & $132^{\circ}$ \\
\hline & & $16^{\circ}$ & $129^{\circ}$ & $50^{\circ}$ & $133^{\circ}$ \\
\hline & & $12^{\circ}$ & $133^{\circ}$ & $41^{\circ}$ & $134^{\circ}$ \\
\hline & & $12^{\circ}$ & $133^{\circ}$ & $42^{\circ}$ & $135^{\circ}$ \\
\hline & & $11^{\circ}$ & $135^{\circ}$ & $40^{\circ}$ & $135^{\circ}$ \\
\hline & & $20^{\circ}$ & $138^{\circ}$ & $55^{\circ}$ & $136^{\circ}$ \\
\hline & & $16^{\circ}$ & $137^{\circ}$ & $55^{\circ}$ & $137^{\circ}$ \\
\hline & & $17^{\circ}$ & $142^{\circ}$ & $53^{\circ}$ & $137^{\circ}$ \\
\hline & & $28^{\circ}$ & $141^{\circ}$ & $55^{\circ}$ & $135^{\circ}$ \\
\hline & & & & $55^{\circ}$ & $136^{\circ}$ \\
\hline & & $16^{\circ}$ & $138^{\circ}$ & $58^{\circ}$ & $136^{\circ}$ \\
\hline & & $14^{\circ}$ & $134^{\circ}$ & $59^{\circ}$ & $137^{\circ}$ \\
\hline & & $29^{\circ}$ & $142^{\circ}$ & $60^{\circ}$ & $136^{\circ}$ \\
\hline & & $21^{\circ}$ & $136^{\circ}$ & $56^{\circ}$ & $135^{\circ}$ \\
\hline & & $17^{\circ}$ & $135^{\circ}$ & $50^{\circ}$ & $135^{\circ}$ \\
\hline & & & & $46^{\circ}$ & $135^{\circ}$ \\
\hline & & & & $47^{\circ}$ & $134^{\circ}$ \\
\hline & & & & $51^{\circ}$ & $133^{\circ}$ \\
\hline & & & & $51^{\circ}$ & $134^{\circ}$ \\
\hline \multirow[t]{31}{*}{ MP } & basal unit & & & $30^{\circ}$ & $90^{\circ}$ \\
\hline & & & & $32^{\circ}$ & $89^{\circ}$ \\
\hline & & & & $32^{\circ}$ & $88^{\circ}$ \\
\hline & & & & $30^{\circ}$ & $89^{\circ}$ \\
\hline & & $20^{\circ}$ & $80^{\circ}$ & $10^{\circ}$ & $80^{\circ}$ \\
\hline & & & & $12^{\circ}$ & $80^{\circ}$ \\
\hline & & & & $15^{\circ}$ & $81^{\circ}$ \\
\hline & & & & $12^{\circ}$ & $80^{\circ}$ \\
\hline & & & & $13^{\circ}$ & $81^{\circ}$ \\
\hline & & $37^{\circ}$ & $87^{\circ}$ & $21^{\circ}$ & $92^{\circ}$ \\
\hline & & & & $24^{\circ}$ & $91^{\circ}$ \\
\hline & & & & $21^{\circ}$ & $91^{\circ}$ \\
\hline & & & & $23^{\circ}$ & $92^{\circ}$ \\
\hline & upper unit & $30^{\circ}$ & $80^{\circ}$ & $25^{\circ}$ & $92^{\circ}$ \\
\hline & & & & $22^{\circ}$ & $92^{\circ}$ \\
\hline & & & & $23^{\circ}$ & $92^{\circ}$ \\
\hline & & & & $25^{\circ}$ & $91^{\circ}$ \\
\hline & & & & $30^{\circ}$ & $90^{\circ}$ \\
\hline & & & & $31^{\circ}$ & $91^{\circ}$ \\
\hline & & & & $29^{\circ}$ & $91^{\circ}$ \\
\hline & & & & $30^{\circ}$ & $91^{\circ}$ \\
\hline & & $20^{\circ}$ & $87^{\circ}$ & $18^{\circ}$ & $87^{\circ}$ \\
\hline & & $22^{\circ}$ & $85^{\circ}$ & $19^{\circ}$ & $87^{\circ}$ \\
\hline & & $20^{\circ}$ & $80^{\circ}$ & $22^{\circ}$ & $88^{\circ}$ \\
\hline & & $15^{\circ}$ & $87^{\circ}$ & $18^{\circ}$ & $88^{\circ}$ \\
\hline & & & & $16^{\circ}$ & $88^{\circ}$ \\
\hline & & & & $10^{\circ}$ & $87^{\circ}$ \\
\hline & & $30^{\circ}$ & $90^{\circ}$ & $29^{\circ}$ & $93^{\circ}$ \\
\hline & & & & $30^{\circ}$ & $94^{\circ}$ \\
\hline & & & & $31^{\circ}$ & $92^{\circ}$ \\
\hline & & & & $28^{\circ}$ & $91^{\circ}$ \\
\hline \multirow[t]{5}{*}{$\mathrm{PA}$} & & $30^{\circ}$ & $340^{\circ}$ & & \\
\hline & & $42^{\circ}$ & $345^{\circ}$ & & \\
\hline & & $22^{\circ}$ & $285^{\circ}$ & & \\
\hline & & $46^{\circ}$ & $352^{\circ}$ & & \\
\hline & & $30^{\circ}$ & $338^{\circ}$ & & \\
\hline
\end{tabular}

TABLE 5.- Statistical indices of the studied eolian deposits.

\begin{tabular}{|c|c|c|c|c|}
\hline \multirow{2}{*}{$\begin{array}{l}\text { Parameters } \\
\text { textural indices }[\mathrm{mm}]\end{array}$} & \multirow{2}{*}{$\begin{array}{c}\text { Indices } \\
\text { Mo }\end{array}$} & \multicolumn{3}{|c|}{ Modern DunesFossil Dunes } \\
\hline & & 0.15 & & 0.15 \\
\hline & Md & 0.21 & & 0.24 \\
\hline & $M$ & 0.29 & & 0.30 \\
\hline & $\mathrm{s}$ & 0.22 & & 0.19 \\
\hline \multicolumn{2}{|c|}{ probability of the hypothesis test for the textural means } & & 0.99 & \\
\hline \multirow[t]{3}{*}{ bulk sediment density $\left[\mathrm{kg} / \mathrm{m}^{3}\right]$} & $\rho_{\text {med }}$ & 1611 & & 1209 \\
\hline & $\rho_{\max }$ & 1681 & & 1456 \\
\hline & $\rho_{\min }$ & 1560 & & 947 \\
\hline Pearson correlation coefficient & $\mathrm{r}$ & 0.93 & & \\
\hline coefficient of linear determination & $\mathrm{R}^{2}$ & 0.87 & & \\
\hline
\end{tabular}

$M_{o}$, textural mode; $M_{d}$, textural median; $M$, textural mean; s, textural standard deviation; $\rho_{\text {med }}$, mean density; $\rho_{\max }$, the highest measured density; $\rho_{\min }$, the lowest measured density.

this study utilizes the models of Bagnold (1954) and Zingg (1953) because they represent most accurately the local wind dynamics at the study area.

Physical eolian models, such as the formulations of Bagnold (1954), were obtained under ideal conditions involving i) flat dry surfaces, ii) unconsolidated and noncohesive sediments, and iii) the absence of vegetation. Evidently, natural systems are more complex, and the study area does not strictly fit these ideal conditions. Concerning the morphology of the surface in the study area, the low-lying areas are more likely flat. From the Las Burras River and up to the eastern side, the basin floor is nearly flat, especially through the salar. However, the eastern and western basin margins are defined by mountains, and their effect on the local eolian system is not being considered in this research. The study area fits fairly well the remaining conditions of the physical formulations: the present regional aridity determines that the alluvial piedmonts, the ephemeral stream channels, and the alluvial plains of permanent rivers like the Las Burras and Miraflores (Fig. 1) are largely dry surfaces throughout the year; the substrate exposed to wind is unconsolidated and noncohesive sediments; and the effect of the vegetation on the wind transport is considered to be negligible because plants reach only a few centimeters in height and are sparsely distributed. These conditions would have been similar during the past, according to paleohydrological studies revealing that hyperaridity has been a dominant feature since the Miocene (Alonso et al. 1991; Alonso et al. 2006; Hartley and Chong 2002b, among others).

Two major concerns are, however, limiting the reliability of inferring wind paleo-dynamics: i) the differences between the characteristics of the natural system when strictly compared with the ideal conditions that underlie the physical models of wind transport and, ii) the simplicity of the necessary assumptions with regard to sediment supply (the maximum grain sizes in fossil dunes represent the maximum wind-speed conditions during the past, based on considering that there was an unlimited supply of particles of all sizes), because there could be other limiting factors, such as the available grain sizes in the source area.

Although i) the model of Bagnold offers an apparent good predictability for the study area, and ii) despite the use of statistical analysis in order to constrain interpretations and errors, we however consider that the uncertainties derived from the methodology we apply in this study (e.g., the ideal conditions of the physical formulations, like those regarding the relief of the study area) limit the attempt to quantify the paleo-wind dynamics. According to the variability between the reported meteorological data of wind speed and calculations of $W_{\text {mean }}$ and $W_{\max }$ in the modern eolian system, the error involved in the employed methodology reaches $2.50 \%$ when assessing the grain-size-based modern maximum speed, and $10.64 \%$ for the mean speed. Consequently, we warn the reader of the 
TABLE 6.-Physical eolian parameters on the study region.

\begin{tabular}{|c|c|c|c|c|c|c|c|}
\hline \multirow[b]{2}{*}{$\begin{array}{c}\text { Sampled } \\
\text { Sites }\end{array}$} & \multirow[b]{2}{*}{$\rho \mathrm{kg} / \mathrm{m}^{3}$} & \multicolumn{3}{|c|}{$D_{\text {mean }}$} & \multicolumn{3}{|c|}{$D_{\max }$} \\
\hline & & $\begin{array}{c}D_{\text {mean }} \\
\mathrm{mm}\end{array}$ & $\begin{array}{c}u *_{c} \\
\mathrm{~cm} / \mathrm{s}\end{array}$ & $\begin{array}{c}W_{Z}=2 m \\
\mathrm{~km} / \mathrm{h}\end{array}$ & $\begin{array}{c}D_{\max } \\
\mathrm{mm}\end{array}$ & $\begin{array}{c}u *_{c} \\
\mathrm{~cm} / \mathrm{s}\end{array}$ & $\begin{array}{c}W_{Z}=2 m \\
\mathrm{Km} / \mathrm{h}\end{array}$ \\
\hline \begin{tabular}{|l|}
$\mathrm{LBa}$ \\
$\mathrm{LBb}$
\end{tabular} & 1681 & 0.71 & 37 & 41 & 1 & 44 & 53 \\
\hline LBc & & & & & & & \\
\hline AT & 1566 & 0.18 & 18 & 17 & 1 & 43 & 53 \\
\hline YA & 1676 & 0.25 & 22 & 21 & 0.42 & 28 & 29 \\
\hline $\mathrm{ECa}$ & 1615 & 0.25 & 21 & 21 & 0.42 & 28 & 29 \\
\hline $\mathrm{ECc}$ & & 0.50 & 30 & 32 & 1 & 43 & 52 \\
\hline AC & 1560 & 0.18 & 18 & 17 & 0.42 & 27 & 29 \\
\hline $\mathrm{ABa}$ & 1560 & 0.12 & 15 & 14 & 1 & 42 & 52 \\
\hline $\mathrm{ABb}$ & & 0.25 & 21 & 21 & 1.68 & 54 & 77 \\
\hline SA & 1560 & 0.18 & 18 & 17 & 0.42 & 27 & 29 \\
\hline AP & 1560 & 0.18 & 18 & 17 & 0.42 & 27 & 29 \\
\hline $\mathrm{POa}$ & 1615 & 0.25 & 21 & 21 & 0.42 & 28 & 29 \\
\hline $\mathrm{POb}$ & & & & & & & \\
\hline $\mathrm{AL}$ & 1458 & 0.50 & 29 & 32 & 0.71 & 34 & 40 \\
\hline MPa & 1020 & 0.25 & 17 & 18 & 1.68 & 44 & 73 \\
\hline $\mathrm{MPb}$ & 947 & 0.12 & 12 & 12 & 1 & 33 & 48 \\
\hline MPc & & & & & & & \\
\hline PAa & 1456 & 0.25 & 20 & 22 & 0.50 & 29 & 32 \\
\hline PAb & & 0.42 & 26 & 28 & 1 & 40 & 51 \\
\hline
\end{tabular}

$\rho$, mean density of eolian sands from the considered sampled sites; $D$, textura mean; $u_{*}$, critical wind shear velocity; $W_{Z}=2 m$, mean wind velocity value at height $z$ above the boundary surface for $D_{\text {mean }} ; D_{\max }$, the coarsest grain size of the considered sample; $W_{Z=2 m}$, maximum wind velocity value at height $z=2 \mathrm{~m}$ above the boundary surface and for $D_{\max }$ inference of wind-paleo velocity from grain sizes remains a broad approach to the past eolian system.

\section{RESULTS}

\section{Modern Eolian Deposits}

Modern Eolian Landforms.-Eolian landforms covering the Salinas Grandes-Guayatayoc basin (SGG) include longitudinal dunes through the western margin (samples LB) and transverse dunes and barchans in the middle part (Fig. 2). This continuous dunefield increases in height towards the Alta Range. Field observations during windstorms revealed that the stream channels of the Las Burras River are the source of much of the SGG eolian sediment.

From the stream channels of the Las Burras River, sediments are transported eastward over $25 \mathrm{~km}$ and reach the mountain foothills of the Alta Range, where climbing dunes cover the western flank (samples AT). These dunes climb up and migrate out of the basin, where they become falling dunes (samples YA) along the eastern flank of the Alta Range.

Minor sand accumulations develop along the borders of the SGG basin. These deposits include the eolian sites of El Colorado (samples EC), Agua de Castilla (AC), Abra Laite (AB), and Sayate (SA; Figs. 1, 2), which include nebkas and isolated dunes up to 1 meter high.

In the northern part of the studied area, eolian deposits are often found on the eastern sides of the mountains. For instance, the orographic lee slope in Abra Pampa (Fig. 1) corresponds to an echo dune locally referred to as Huancar de Abra Pampa (the Quecha term of huancar refers to eolian dunes and dunefields). Next to Abra Pampa, the Miraflores River flows transversely to the wind direction. Sediments are transported eastward from this stream channel and reach the Potrero Range (3900 m asl), which constitutes a $600-\mathrm{m}$-high topographic obstacle for airflows (Fig. 3). The

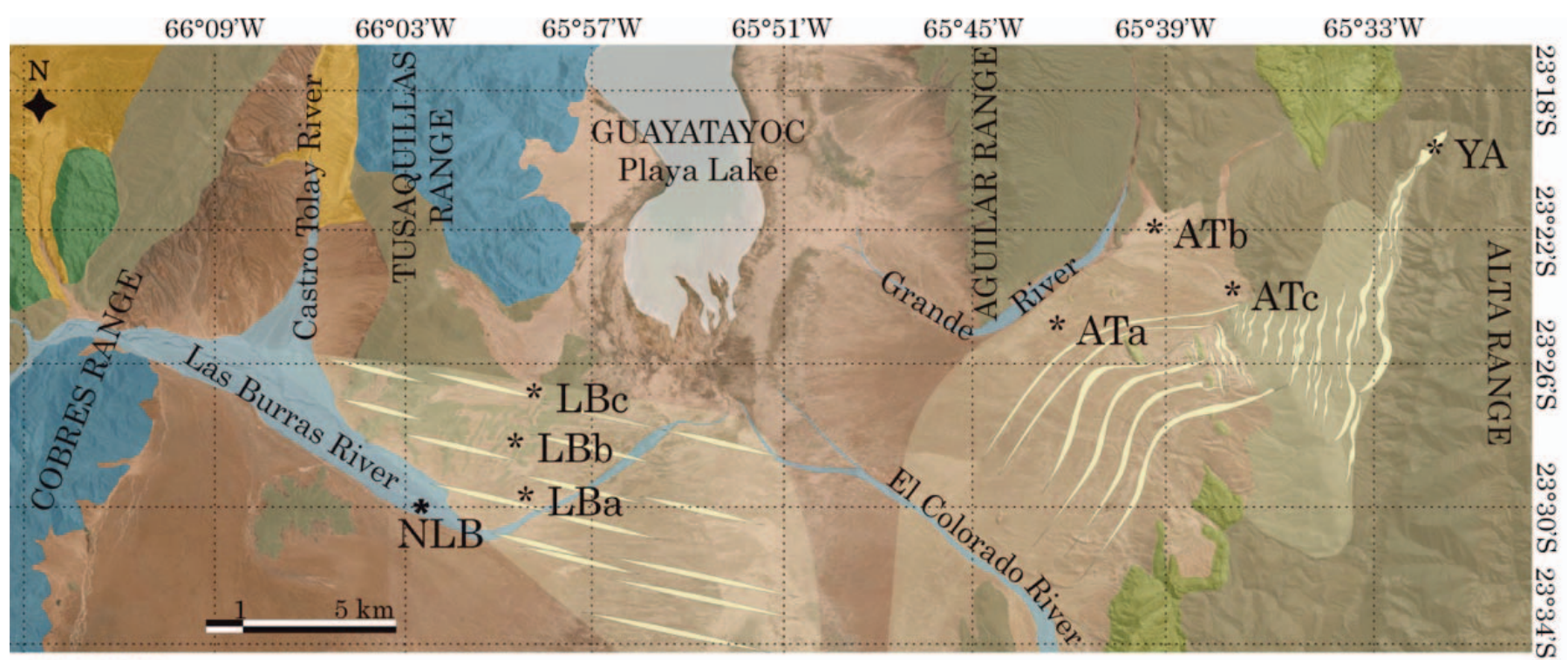

\section{LEGEND}

Eolian deposits (Holocene)

Sandy river-flood plain

Playa lake and salar (upper Holocene)
Alluvial deposits (upper

Pleistocene - middle Holocene)

Ignimbrites (upper Miocene)

Salta Group

(Cretaceous · middle Eocene)

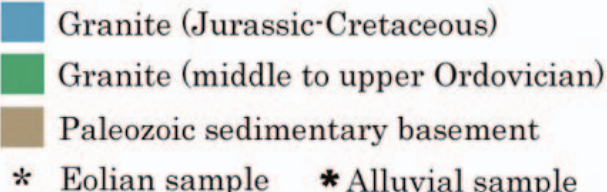

* Eolian sample * Alluvial sample

FIG. 2.-Salinas Grandes-Guayatayoc (SGG) dunefield map. The wind direction is from NW, parallel to longitudinal dunes (LB) covering the Las Burras alluvial fan. At the foot of the Alta Range, the slope controls the development of transversal dunes (AT). The Yacoraite falling dunes (YA) involve sediments that migrated out of the SGG basin. Sampled sites are identified by black stars 

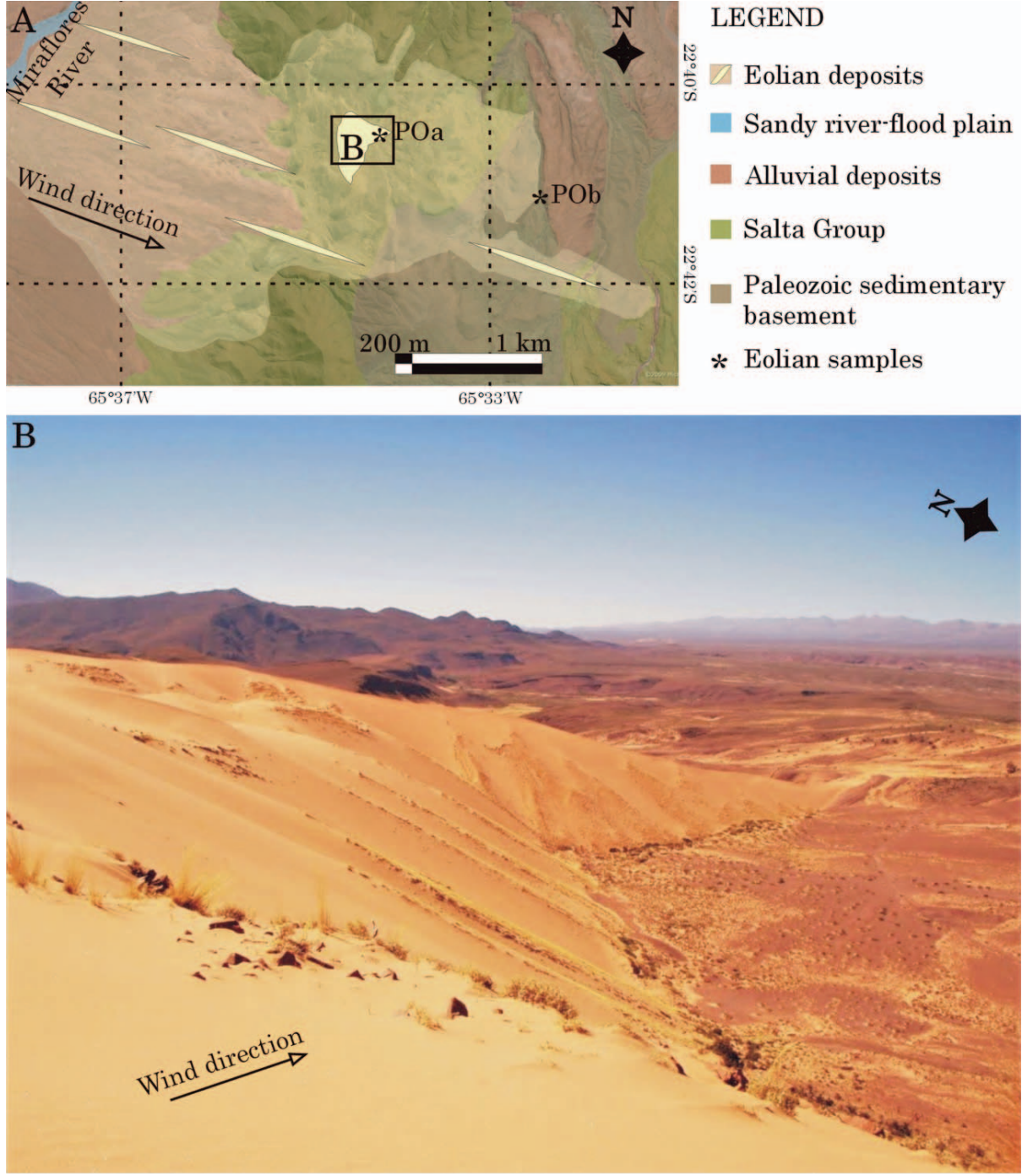

FIG. 3-A) The dunefield of Potrero. Alluvial deposits are upper Pleistocene-middle Holocene, and eolian deposits are Holocene to modern. B) The Potrero star dune in the eastern flank of the Potrero Range. affected sediment flux produces a $15-\mathrm{m}$-high, $520 \mathrm{~m}^{2}$ large star dune in the eastern flank of the Potrero Range, and a $15 \mathrm{~km}^{2}$ dunefield towards the east.

Modern Eolian Sedimentology.-Modern eolian deposits are medium sands (Fig. 4, Table 2) characterized by a $M$ of $0.29 \mathrm{~mm}$, with $\mathrm{s}=0.22$ (Table 5). With the exception of the Las Burras dunes, modern eolian deposits are unimodal (Fig. 4). There are no fractions finer than $0.03 \mathrm{~mm}$, and very coarse sands represent up to $4 \%$ of the distribution (Table 2). Las Burras longitudinal dunes are composed of bimodal, very coarse sands and medium sands (Fig. 4). The stream channel of the Las Burras River is composed of bimodal sediments of fine pebble and fine sand. Grains between 2 and $25 \mathrm{~mm}$ in diameter represent $>57 \%$, and the fraction finer than $0.03 \mathrm{~mm}$ is $0.50 \%$ (sample NLB, Table 2).

The mean density of modern eolian sands is $1611 \mathrm{~kg} / \mathrm{m}^{3}$ (Table 5). Lithic fractions usually include more than $80 \%$ of quartz grains, and variable proportions of calcareous sandstone and mudstone, siliceous shalestone, and granite.

Field observation reveals that the color of these eolian deposits is a distinctive feature. For example, eolian sands in Salinas GrandesGuayatayoc and Agua de Castilla are typically yellowish brown, whereas the Potrero star dune is reddish. LB samples are composed of angular to subrounded grains which include $80 \%$ of quartz and $\sim 20 \%$ of green-gray clasts of granite and metasedimentary fragments from the Santa Victoria Group (Fig. 5, Table 3). Samples AC, AB, and SA contain well sorted, rounded, and polished grains. These sands are composed of more than $80 \%$ quartz grains, and 10 to $15 \%$ of green and dark gray shales and sandstones clasts, similar to the Santa Victoria Group, and the granite lithotype represents $4 \%$. PO samples are composed mainly of quartz, which include up to $78 \%$ of reddish quartz grains. These well sorted, rounded and polished sands also include up to $12 \%$ of red sandstones and limestones sourced from the Pirgua Subgroup (Fig. 5, Table 3).

The colored sands of SGG and PO gradually fade and turn into whitish and pale pink as sediments move away from the source area. The proportion of lithic fragments progressively decreases eastward away from the source area. Samples AT, YA, EC, and AP contain well sorted, rounded, and polished grains, represented mainly $(>90 \%)$ by quartz (Fig. 5, Table 3).

Dynamics of Modern Eolian Transport.-The average modern wind speed $\left(W_{\text {med }}=23.50 \mathrm{~km} / \mathrm{h}\right.$; Bianchi 1981; Bianchi and Yáñez 1992; Buitrago and Larran 1994; Bianchi and Yáñez 2005) creates critical shear velocities that are sufficient to overcome the movement threshold of sediment sizes up to $D=0.42 \mathrm{~mm}$, which include all fractions smaller 

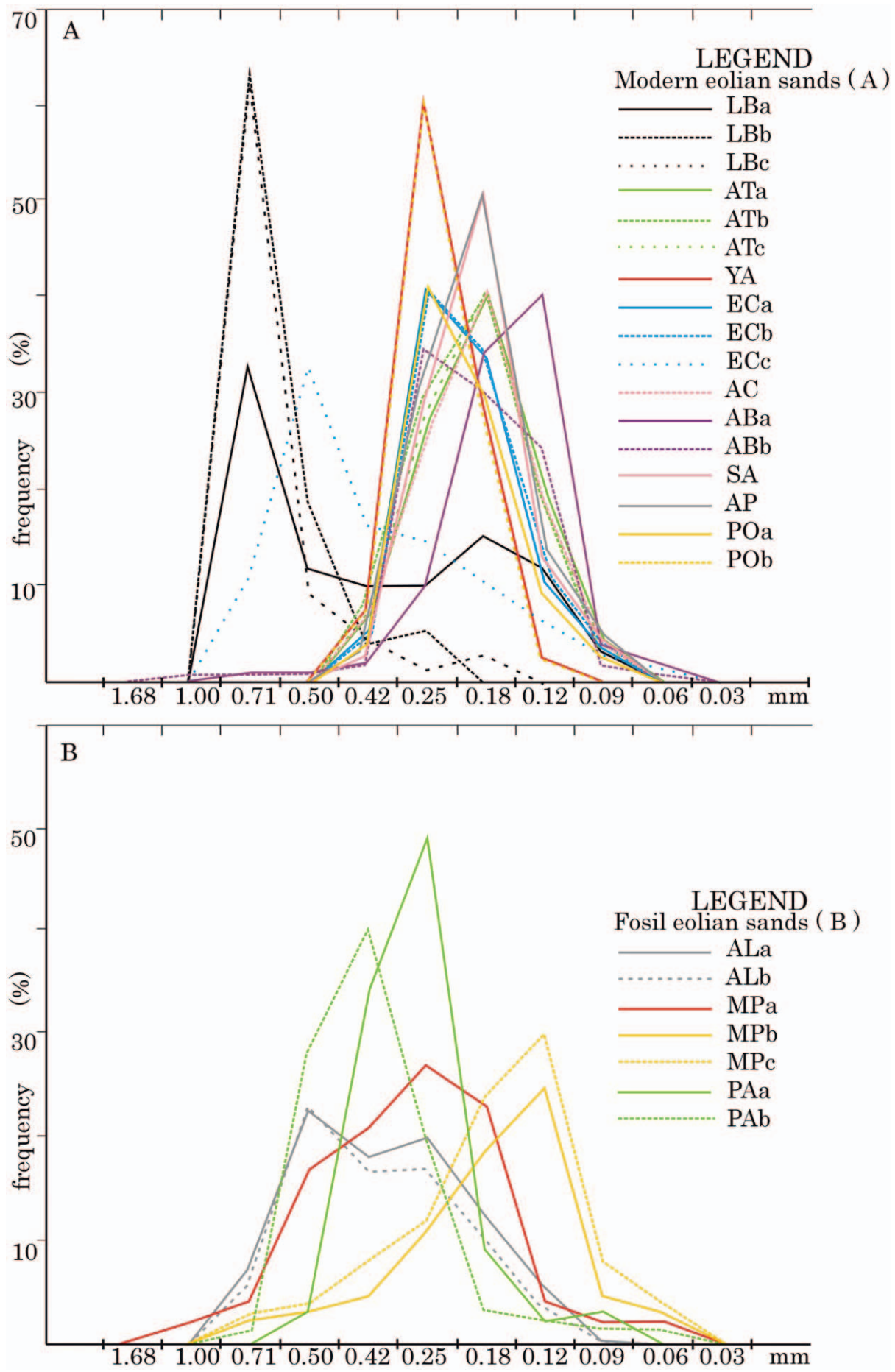

FIG. 4.- Textural frequencies of A) modern and B) fossil eolian sediments.

than the $M$ (Table 6). Critical wind shear velocities up to $1.08 \mathrm{~km} / \mathrm{h}$ are capable of mobilizing medium sands with densities between 1560 and $1676 \mathrm{~kg} / \mathrm{m}^{3}$. The displacement of coarser grains requires a greater energy-flow. Eolian erosion of very coarse sands (for example the $D_{\max }$ fractions of sample $\mathrm{AB}_{\mathrm{b}}, \rho=1560 \mathrm{~kg} / \mathrm{m}^{3}$ ) requires wind velocities up to $77 \mathrm{~km} / \mathrm{h}$ (Table 6). This wind speed can be attained based on the modern maximum wind speed reported in the study area $(80 \mathrm{~km} / \mathrm{h}$; Bianchi 1981 ; Bianchi and Yáñez 1992; Buitrago and Larran 1994; Bianchi and Yáñez 2005).

\section{Fossil Eolian Deposits}

Fossil eolian deposits are characterized by a mean density of $1209 \mathrm{~kg} / \mathrm{m}^{3}$ and $M$ is 0.30 , with $\mathrm{s}=0.19$ (Table 5). These medium sands contain no fractions less than $0.03 \mathrm{~mm}$, and samples AL and PAa are coarser than 0.08 $\mathrm{mm}$ (Table 2). Sand fractions including grains coarser than $0.78 \mathrm{~mm}$ and up to $1.68 \mathrm{~mm}$ in diameter represent 2 to $7 \%$.

The Fossil Eolian Deposit of Alfarcito.-The Alfarcito (AL) fossil dune is located on the eastern flank of the Tusaquillas Range (Fig. 1). 

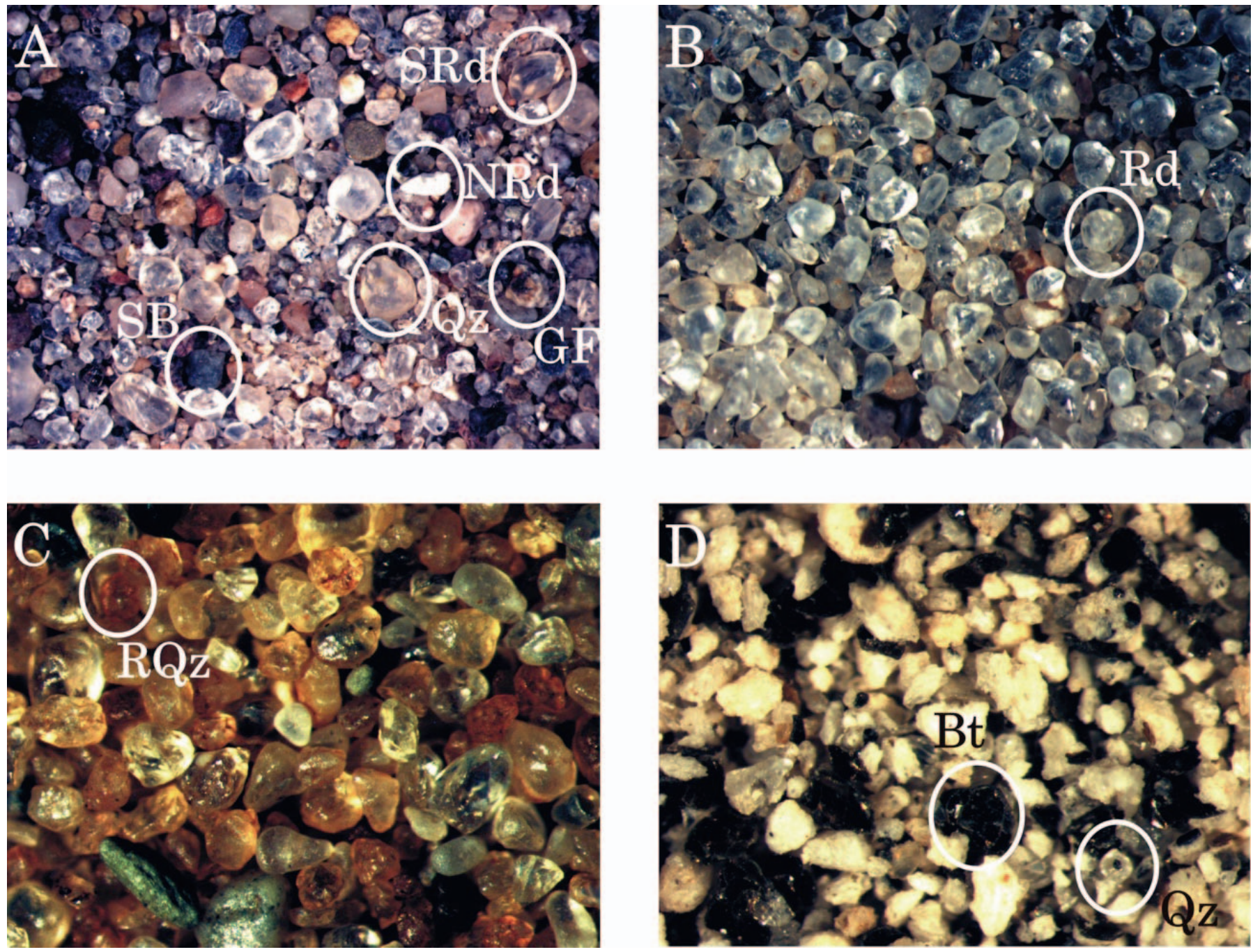

FIG. 5.-Photomicrographs showing details of the eolian samples. A) Sample LB is characterized by grains with alluvial-like morphologies; sands are composed by subrounded quartz and lithic fragments. B) Sample AT contain well sorted and polished grains, represented mainly by quartz. C) Sample PO is composed of reddish sands. D) Fossil eolian sands from Mal Paso are composed of quartz, vitric fragments, and abundant biotite. GF, granitic fragment; SB, clast from the sedimentary basement; Qz, quartz grain; NRd, not rounded grain; SRd, sub-rounded grain; Rd, rounded grain; RQz, reddish quartz grain; Bt, biotite.

Alluvial processes of the Alfarcito River caused the outcrop of this fossil eolian deposit along $250 \mathrm{~m}$ (Fig. 6). The deposit is more than $25 \mathrm{~m}$ thick and is truncated by an erosional unconformity. Upper Pleistocene conglomerates (López Steinmetz and Galli 2015) overlie the AL fossil dune. The AL outcrop exposes well-preserved sedimentary structures. Reactivation surfaces and sets of cross-strata tilt towards the SE (Fig. 7, Table 4).

The color of the fossil eolian deposit stands out from both the brownish geological landscape and the yellowish brown modern dunes. The mineralogy of the Alfarcito fossil eolian sands comprises up to $60 \%$ of volcanic lithotypes, which include biotite and vitric fragments (i.e., glass shards; Fig. 5, Table 3). The AL fossil dune is composed of unconsolidated, bimodal coarse sands and contains up to $3 \%$ very coarse fractions. The density of these fossil eolian sands is $1458 \mathrm{~kg} / \mathrm{m}^{3}$.

The Fossil Eolian Deposit of Pabellón.-The fossil dune of Pabellón (PA) is located on the western flank of the Aguilar Range (Fig. 1). This 4m-thick outcrop shows the basal contact between the studied deposit and a polymictic conglomerate containing an abundant muddy matrix, and is interpreted to have been caused by mud flows (Fig. 8). The PA fossil dune is truncated by an erosional unconformity and is overlain by coarse, polymictic and alluvial deposits assigned to the upper Pleistocene (López Steinmetz and Galli 2015).

The PA outcrop exhibits reactivation surfaces and sets of cross-strata that incline similar to the topography in a NW direction (Fig. 8, Table 4). The PA eolian deposit is characterized by unconsolidated medium to coarse sands with up to $3 \%$ very coarse sands, and the density is $1456 \mathrm{~kg} / \mathrm{m}^{3}$. Eolian sands are composed mainly of quartz grains, lithics sourced from the Santa Victoria Group, and up to $30 \%$ of volcanic lithotypes, including vitric fragments and biotites (Table 3 ).

The Fossil Eolian Deposit of Mal Paso.-The outcrop of Mal Paso (MP) is located along Road 52, in the Quebrada de Mal Paso, in the northern part of the Cobres Range (Fig. 1). This outcrop exhibits a 9-mthick fossil dune that overlies a paleo-relief eroded onto the Santa Victoria Group bedrock. The top of the MP eolian deposit is truncated by an erosional unconformity and is overlain by coarse polymictic alluvial conglomerates. 

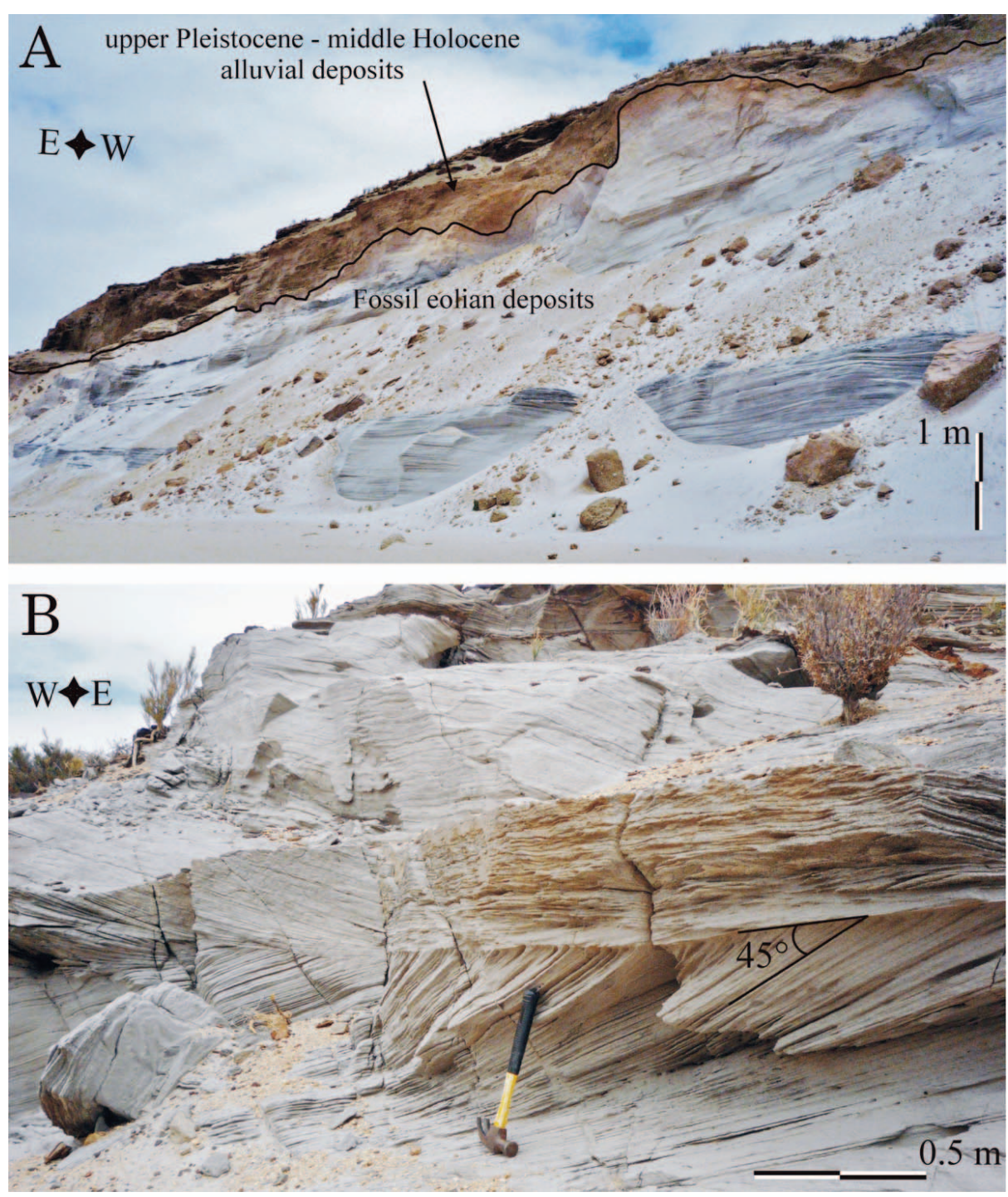

Fig. 6.-A) The Alfarcito outcrop exposes fossil eolian deposit along $250 \mathrm{~m}$. B) The Alfarcito fossil dune and the cross stratification dipping $45^{\circ}$.
Eolian stratigraphic architectures include reactivation surfaces and cross-beds that incline towards the SE (Fig. 8, Table 4). The MP deposit includes two eolian units. The whitish basal unit is composed of unconsolidated medium to coarse sands with a density of $1020 \mathrm{~kg} / \mathrm{m}^{3}$. An erosional surface truncates the basal unit. Polymictic conglomerates rich in Santa Victoria Group boulders are intercalated between the two eolian units. The grayish upper eolian unit is composed of unconsolidated medium to fine sands with up to $3 \%$ very coarse fractions. The density of sediments from the upper unit is $947 \mathrm{~kg} / \mathrm{m}^{3}$.

The color difference between the two eolian units is related to the abundance of volcanic lithotypes in sands. Vitric fragments (glass shards) represent up to $31 \%$ in the basal unit, while the top is biotite rich (Table $3)$.

Dynamics of Fossil Eolian Transport.-The mean sedimentary fractions $(D)$ implies $W_{\text {mean }}$ to be between 12 and $29 \mathrm{~km} / \mathrm{h}$ (Table 6). The presence of the coarsest grains, those up to $1.68 \mathrm{~mm}$ in diameter $\left(D_{\max }\right)$, implies that wind gusts would have reached $73 \mathrm{~km} / \mathrm{h}$ (Table 6, Fig. 9).

\section{DISCUSSION}

\section{Age of the Fossil Dunes}

The absence of modern volcanics-rich deposits (gray dunes) indicates that the sediment supply path controlling the development of these dunes is not currently active. The availability of considerable volcanics-rich and wind-erodible sediment volumes that fed fossil dunes was most likely related to volcanic eruptions. In the study region, the main volcanic activity occurred during the late Miocene between 8 and $7 \mathrm{Ma}$, and widespread volcanism continued until the Pliocene (Seggiaro and Aniel 1989; Soler et al. 2007; Kay and Coira 2009; Kay et al. 2010). Furthermore, the presence of eolian dunes in the sedimentary records is regionally constrained to the Miocene (e.g., Díaz and Malizzia 1983; Kraemer et al. 1999; Voss 2002; Dávila and Astini 2003; Carrapa et al. 2005; del Papa et al. 2013a). Additionally, these ages coincide with the occurrence of significant volumes of evaporites, evidence that aridity was the prevailing regional environment (Alonso 1986; Chong 1988; Alonso et al. 1991; Vandervoort et al. 1995; Hartley and Chong 2002a; among others). Therefore, the formation of the fossil dunes most likely began during the Miocene, in 

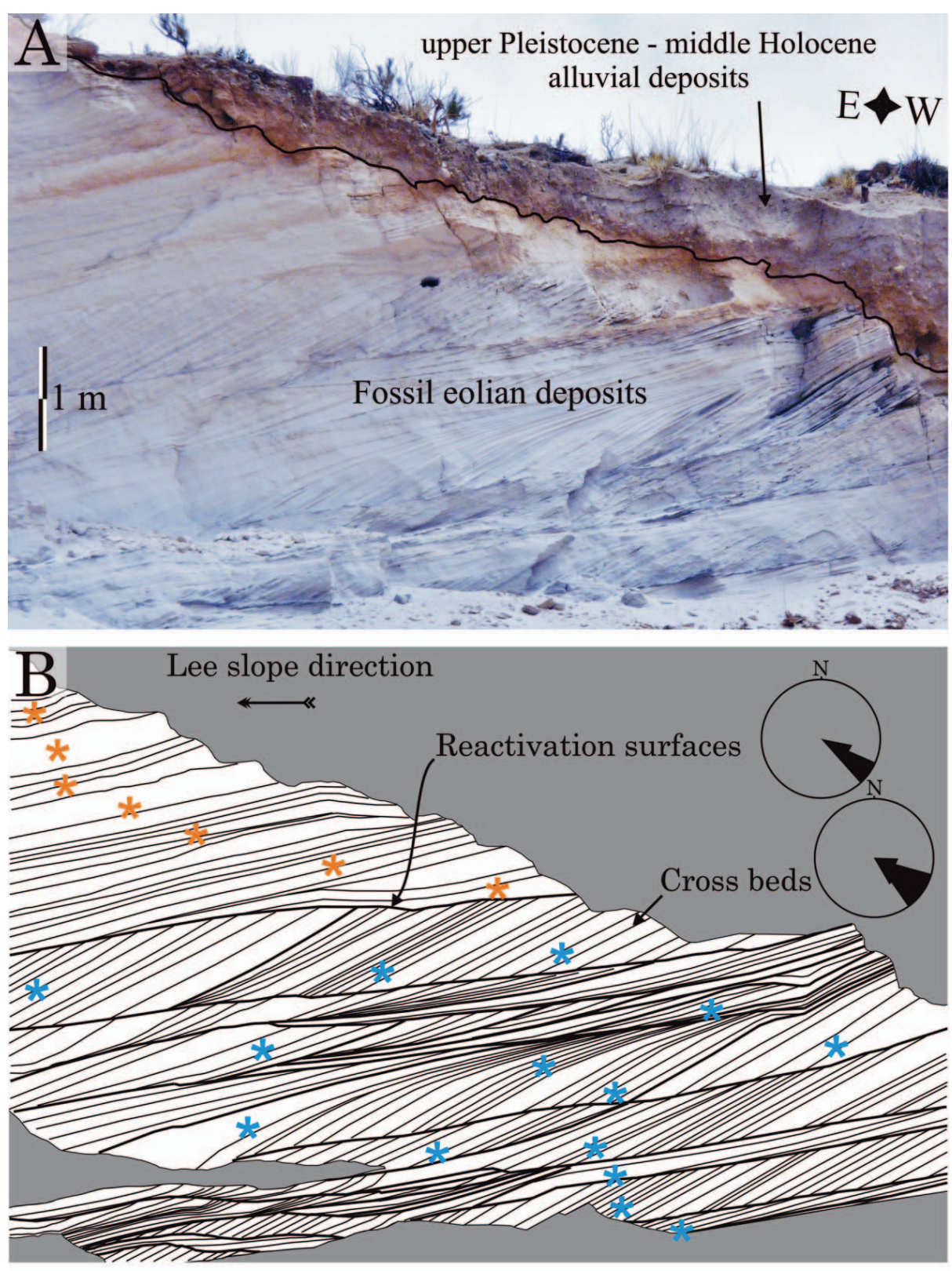

* ALa samples

* ALb samples
FIg. 7.-A) The Alfarcito outcrop exposes well-preserved sedimentary structures. B) Reactivation surfaces and set of cross strata dip towards the SE. association with the eruptive processes of the Coranzuli volcano, which is a maximum age limit.

More humid conditions developed between $150 \mathrm{kyr}$ and the Pleistocene-Holocene transition (Zipprich et al. 1999; Zech et al. 2009a, 2009b; McGlue et al. 2013; Fritz et al. 2004; López Steinmetz and Galli 2015). According to this, fossil dunes should have formed earlier than the middle to late Pleistocene, which is a minimum age limit.

The age of the fossil eolian deposits cannot be accurately established due to the absence of absolute chronological data. Quartz and feldspar luminescence dating is the widely employed method for eolian deposits (Singhvi et al. 2001; Preusser et al. 2008). However, the temporal range limit of luminescence dating is usually ca. $200 \mathrm{ka}$ (Miller et al. 1999; Wolfe et al. 2000). However, $\mathrm{K} / \mathrm{Ar}$ and $\mathrm{Ar} / \mathrm{Ar}$ dating of intercalated tuffs in Miocene fossil eolian deposits through the region yielded $22.5 \pm 0.6 \mathrm{Ma}$ and 21.0 \pm 0.8 Ma (Kraemer et al. 1999; del Papa et al. 2013a).
Consequently, we propose that the studied fossil dunes are more likely late Miocene in age.

\section{The Mineralogy of Fossil and Modern Dunes}

The modern and fossil dunes have sediments of different mineralogical composition. The modern dunes are composed of lithic grains sourced from lithologies cropping out within the basin, including the Santa Victoria Group, granites, and The Pirgua Subgroup, while fossil dunes are composed of biotite- and glass-shard-rich volcanic fragments, with minor proportions of lithic grains. The different mineralogical compositions of the sediments influence densities, which range from $1681 \mathrm{~kg} / \mathrm{m}^{3}$ to $947 \mathrm{~kg} /$ $\mathrm{m}^{3}$, with mean values of 1611 and $1209 \mathrm{~kg} / \mathrm{m}^{3}$ for modern and fossil deposits, respectively.

The formation of modern dunes predominantly involves sediment supplied from dry stream channels, such as the Las Burras, Grande, and 

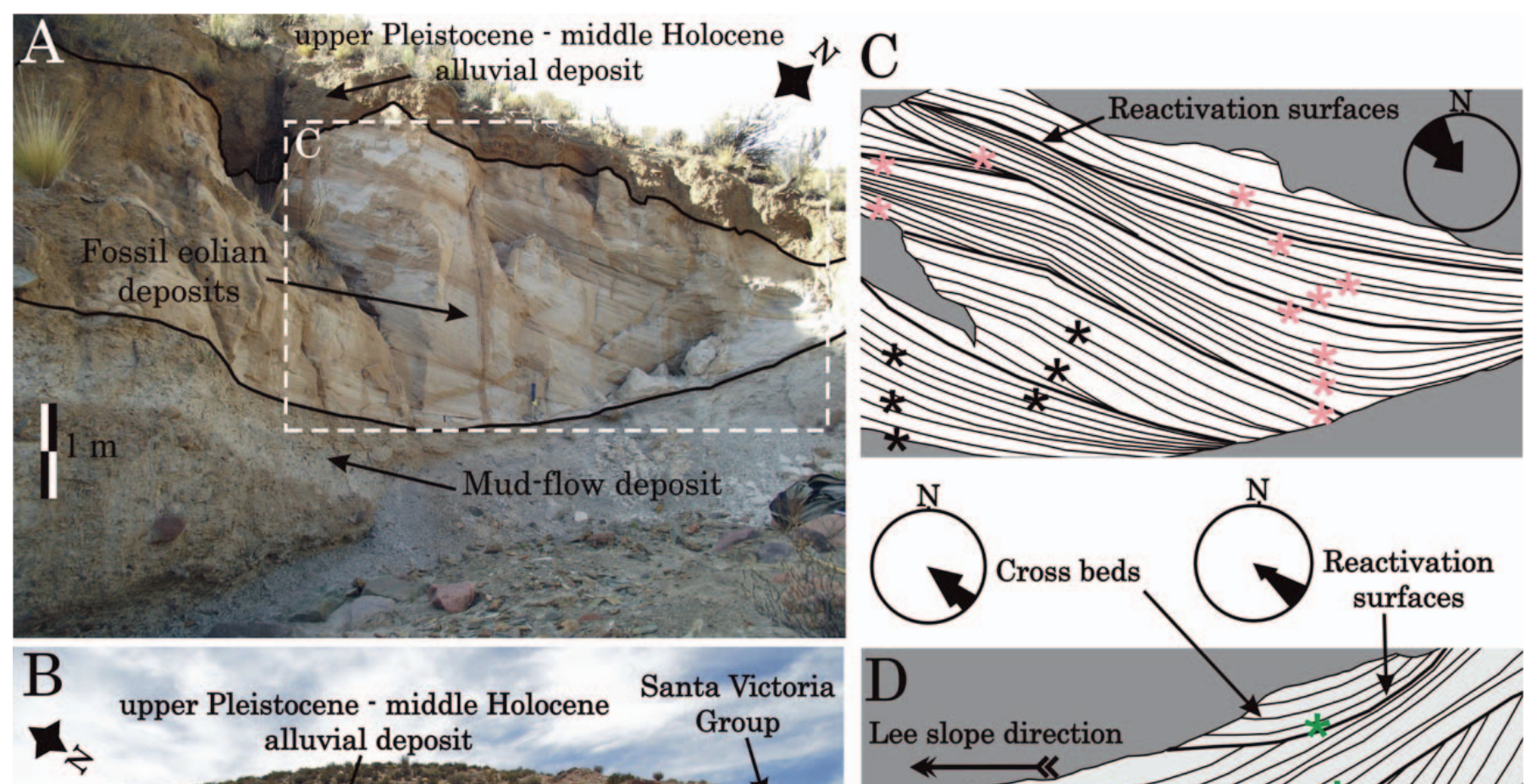

upper Pleistocene - middle Holocene
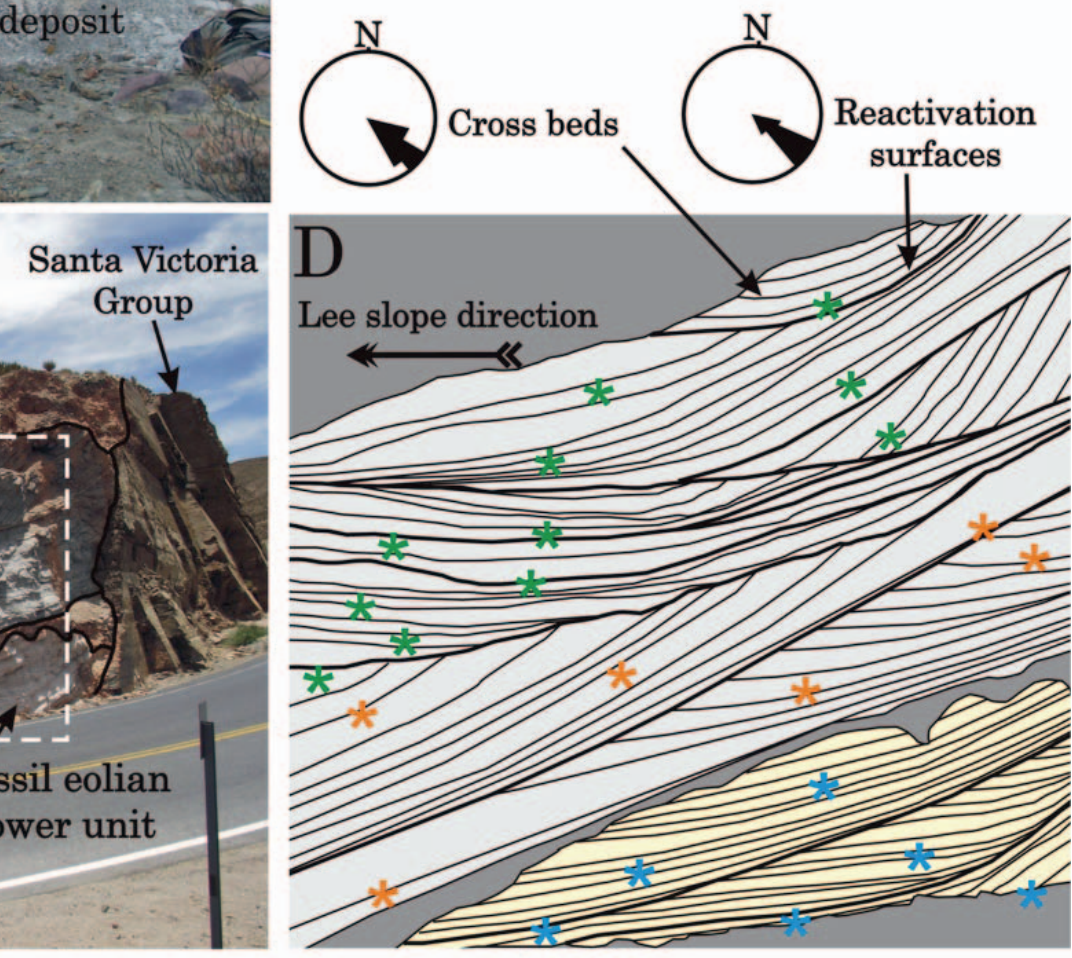

\section{* PAa samples * PAb samples * $\quad$ MPa samples * MPb samples * MPc samples}

Fig. 8.-A) The fossil eolian deposit of Pabellón (PA). B) The fossil eolian deposit of Mal Paso (MP). C) The PA outcrop exhibits sets of cross strata that dip to the NW The outcrop is subparallel to the crestline. D) The MP outcrop is perpendicular to the crest line and exhibits cross beds and bounding surfaces that dip towards the SE.

Miraflores rivers (Fig. 10). The color and the mineralogical composition of eolian sediments indicate that grains are reworked once sediments reach the dunefields: wind erodes dunes proximal to the source region and sediment is transported farther away. For example, grains are eroded from longitudinal dunes next to the Las Burras River and are transported beyond transverse dunes in the flat-lying area in the middle of the basin, and are reworked up to the foot of the Alta Range (Fig. 2). The dynamics of modern dunefields also involves the incorporation of new sediment, which is being permanently deflated from dry surfaces exposed to wind.

The lithological composition of the Pabellón fossil dune indicates that, in addition to sediment deflation from stream channels, the formation of this deposit involved a supply of volcanic fragments. The proportion of these volcanic fractions is greatest in the Mal Paso and Alfarcito fossi dunes. The similar lithological composition of Mal Paso and Alfarcito indicates that these two fossil dunes formed from the same volcanics-rich sediment supply. The mineralogical fractions that characterize modern and fossil dunes suggest that: i) the sediment supply feeding fossil dunes originated from a different source region than that of the modern dunes; ii) the mineralogical composition of the source area that fed fossil dunes was different than the available fractions in modern stream channels.

It cannot be assumed that the modern mechanism of sediment supply, which involves sediment sourced from the deflation of dry surfaces and stream channels, was inactive during the formation of the fossil dunes. On the contrary, the mineralogical fractions in the Pabellón fossil dune show that its formation involved two simultaneous mechanisms and that a change in the geological environment that was conducive to the emergence of an additional source of sediment. This fossil geological environment was characterized by the incorporation of increasing proportions of volcanic fragments into the eolian system. Therefore, during the formation of the fossil dunes the supply of volcanic fragments was proportionally far larger than that of lithic grains sourced from stream channels. 


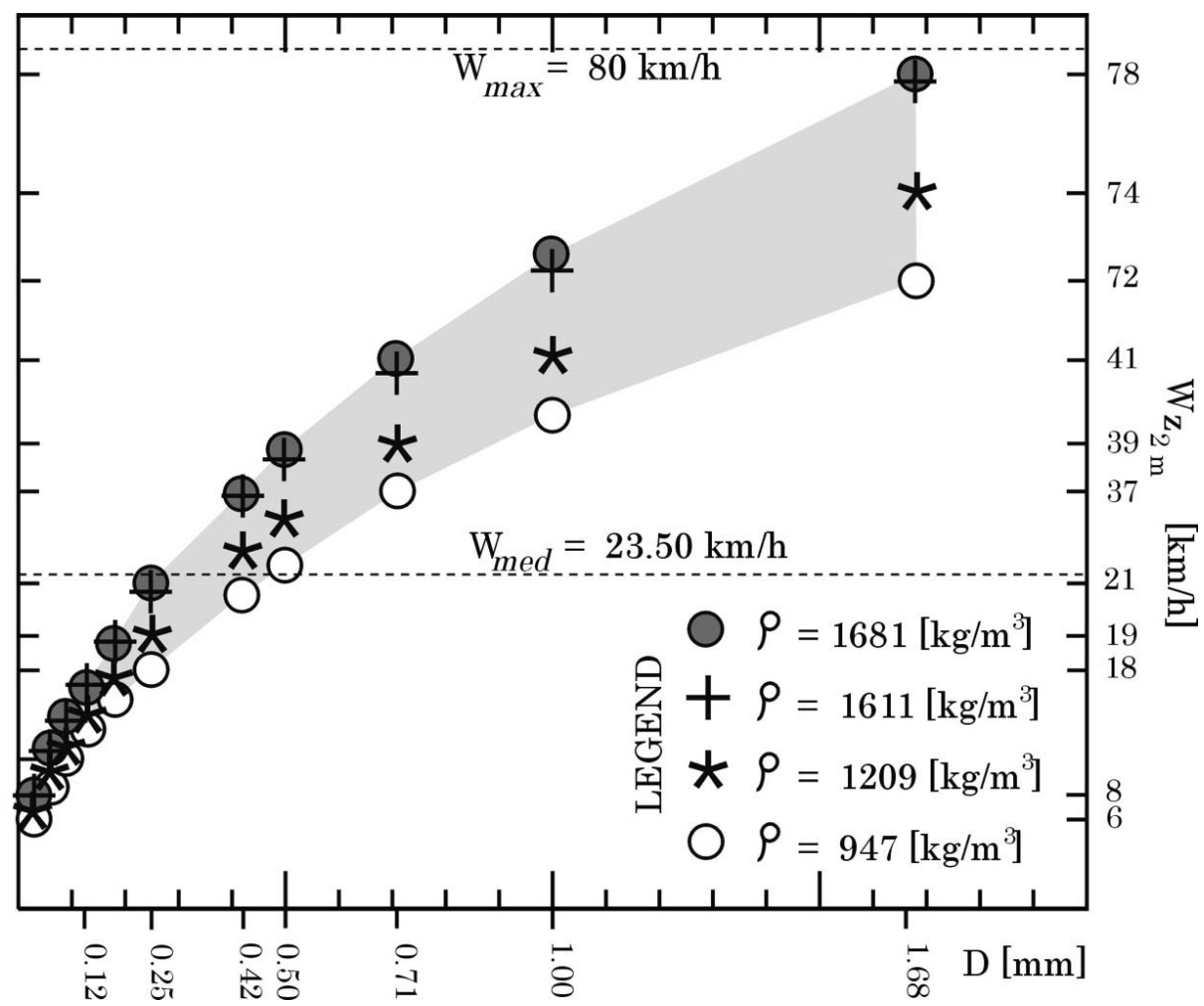

FIG. 9.- Theoretical wind velocity $\left(W_{(z)}\right)$ required for the movement threshold $\left(u_{*_{c}}\right)$ of sediments composed of different grains sizes $(D)$ and densities $(\rho)$, by applying the models of Bagnold (1941, 1954) and Zingg (1953). 1681 and $947 \mathrm{~kg} / \mathrm{m}^{3}$ are the maximum and minimum measured densities in modern and fossil sands, respectively. 1611 and $1209 \mathrm{~kg} / \mathrm{m}^{3}$ are the mean density values for modern and fossil sands, respectively. Fossil and modern eolian sands with $D$ between 0.5 and $0.25 \mathrm{~mm}$, respectively, are susceptible to wind erosion exerted by dynamic conditions similar to the current mean wind speed ( $W_{\text {mean }}=23.50 \mathrm{~km} / \mathrm{h}$, lower horizontal dashed line). The wind speed during the threshold of movement for the observed coarsest grains $\left(D_{\max }\right)$ of fossil and modern dunes depends on the density and varies between 73 and $77 \mathrm{~km} / \mathrm{h}$. $W_{\max }$ is the current maximum wind speed $\left(W_{\max }=80 \mathrm{~km} / \mathrm{h}\right.$, upper horizontal dashed line)
An additional interesting aspect emerging from the mineralogical composition of dunes is related to the fact that modern dunes involve grains from lithologies cropping out within the basin, while the volcanic fractions of the fossil supply needed to be sourced from locations outside the basin. The proportion of the volcanic fractions in fossil dunes is larger in those located along the western side of the study area than those situated in the eastern side. In the modern eolian environment, the influence exerted by the source area on the mineralogical composition of dunes increases in the adjacent locations. This implies that, analogous to the modern system, the Mal Paso and Alfarcito dunes were more influenced by the fossil volcanoclastic source than Pabellón and therefore closer to it.

\section{Direction and Velocity of Wind}

Wind Paleo-Direction.-Spatial arrangements of eolian sedimentary structures are influenced by both the predominant wind direction and the local orography (Fig. 10). Reactivation surfaces and cross beds in the Pabellón fossil dune dip towards the NW, resulting in NE-SW crest-line orientation (Fig. 8A, C). Dune crests of the Alfarcito and Mal Paso are N-S oriented, and the cross bedding and reactivation surfaces are interpreted as evidencing the lee-slope direction (Figs. 7A, 8B, C, respectively). The stratigraphic architecture of fossil dunes accommodated following the orography are similar to the orientation of modern dunes at the foot of the Alta Range. This reveals that the wind paleo-direction was from the NW, which is in agreement with previous observations (Greene 1995; Bailey et al. 2007; de Silva et al. 2010).

The paleo-wind direction and lithological compositions discussed above show that the fossil source region: i) was situated outside the basin, ii) was located westward of the study area, iii) was near the location of Alfarcito and Mal Paso, and iv) was subjected to a large volcanic influence. West of the study area, the Coranzuli volcano is the most prominent and proximal volcanic center (Fig. 1). The late MiocenePliocene activity of this volcano (Seggiaro 1994) involved highly effusive processes generating large volumes of ignimbrites that form the widespread lithology west of the study area (Fig. 1). Therefore, the fossil source region was likely related to the eruptive processes of the Coranzulí volcano.

Wind Paleo-Velocity.-Sedimentary records are closely related to environmental conditions. The sedimentological characterization of dunes can therefore be employed for the assessment of the wind-related environment. We evaluate the fossil and modern eolian environments using statistical analysis. Statistical indices (Table 5) reveal that modern and fossil eolian deposits have the same textural features. In both cases, the most abundant textural fraction corresponds to medium sands. The mean fossil grain size is $0.30 \mathrm{~mm}$, and the mean modern size is $0.29 \mathrm{~mm}$. The hypothesis test of these values shows that the difference between the textural means is not significant, at a significance level $\alpha=0.01\left[t_{\mathrm{o}}(-\right.$ $\left.0.33)<t_{\mathrm{c}}(2.33)\right]$. These results corroborate the null hypothesis, which states that the observed difference between the modern and fossil textural means is null $\left(\mathrm{H}_{0}: \mathrm{M}_{1}=\mathrm{M}_{2}\right)$ with a probability of 0.99 (Table 5). Accordingly, the formation of fossil eolian deposits would have occurred under the same mean wind dynamics as modern dunes (Fig. 9). This means that the wind-related elements of the climate, including wind direction and velocity, have remained unchanged since the Miocene. The alternative is that available sediments in the supply region included only sand sizes below the threshold. In the modern eolian system, alluvial sediments in the stream channel of the Las Burras River include grains up to $25 \mathrm{~mm}$ in diameter, which highlights the control of the wind dynamics rather than the availability of highly sorted sediment at the source region. However, the existence of fractions coarser than those observed in dunes at the fossil source region is uncertain. The lower density of the volcanic lithotype should necessitate a lower entrainment threshold. For example, when $D$ is $1 \mathrm{~mm}, u_{*_{c}}=44 \mathrm{~cm} / \mathrm{s}$ for a density of $1681 \mathrm{~kg} / \mathrm{m}^{3}$ versus $u_{*_{c}}=$ $33 \mathrm{~cm} / \mathrm{s}$ for a density of $947 \mathrm{~kg} / \mathrm{m}^{3}$ (Table 6). Therefore, differences in density and comparable size distributions may indicate weaker past winds. 

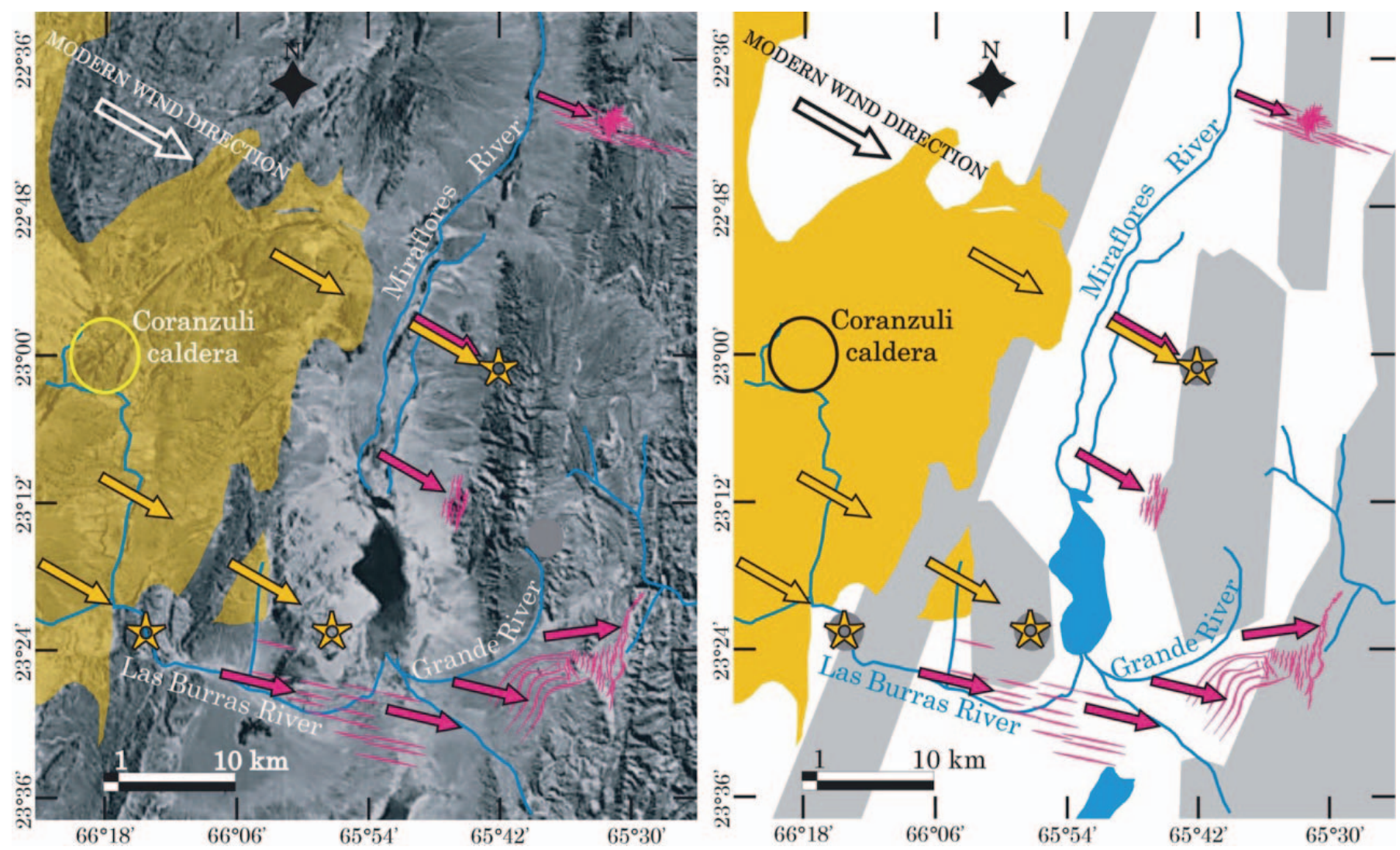

FIG. 10.-Sketch map showing the sediment sources, the sediment store sites, and the inferred transport vectors for the fossil (in yellow) and modern (in pink) eolian systems. Yellow stars, fossil sites of sediments store; pink dunes: modern sites of sediment stores. The sediment source of the fossil eolian system is represented by a yellow area corresponding to the extent of the upper Miocene ignimbrite of the Coranzulí caldera. In the modern eolian system, the source area corresponds to dry surface and stream channels (blue lines) that generally flow perpendicular to the wind direction (white arrow). The inferred transport vectors are represented by yellow and pink arrows for the fossil and modern eolian systems, respectively. Gray areas, highlands; white areas, lowlands; blue areas, salt pans.

\section{Influence of Sediment Availability at the Source Area}

The sedimentary features of the source area are difficult to measure because modeling the availability of suitable-sized sediments is far too complex. In order to better understand the difficulty of assessing the role of the source area in eolian systems, we propose considering the two following, hypothetical sedimentary systems: i) a bimodal mixture of $50 \%$ of $0.03 \mathrm{~mm}$ and $1.68 \mathrm{~mm}$ grain-size sediments; and ii) a system composed of $100 \%$ of $0.25 \mathrm{~mm}$ grains. Sediment traps are placed away downwind in each system. Let's then assume that a constant wind speed higher than the critical wind shear velocity of the hypothesized grain sizes is applied for a period of time long enough to displace all the grains from the original site to the traps of each system. If we were to conduct the experiment, we would be able to observe that after the period of time the trap placed in front of system i accumulated a bimodal sediment mixture of $50 \%$ of $D=$ $0.03 \mathrm{~mm}$ and $1.68 \mathrm{~mm}$, and the trap placed in front of system ii stored all grains of the same size $D=0.25 \mathrm{~mm}$.

Now let's suppose we know neither the wind speed nor the original textural features in either the $\mathrm{i}$ or the ii systems, when observing texture of trapped deposits we could easily conclude that system $i$ was under a faster flow regime than system ii, because transported grain sizes in i are coarser than those in ii. Additionally, it could also be observed that the textura selectivity of wind was more efficient in system $i$ than in system ii, in that the resulting deposits are unimodal and bimodal, respectively. In the hypothesized experiment, wind velocity, however, was the same in both systems and did not control either the maximum transported grain size or the textural distributions. In the experiment, all features of trapped deposits were determined by the available textures of the source area. An example of such a complex scenario is related to some peculiar characteristics of the fossil study dunes.

The modern variability of $W_{\text {mean }}$ and $D_{\text {mean }}$ is $r=0.93$ (Table 5). This correlation $r<1$ indicates that the wind velocity does not entirely explain the textural variability. Therefore, the eolian textural characteristics are being conditioned by other variables that are independent of wind. In modern dunes, the coefficient of determination $R^{2}$ is 0.87 (Table 5). $R^{2}$ represents the variability in sediment textures that can be explained by $W$, and it can also be expressed as a percentage. Results indicate that wind velocity explains $87 \%$ of the modern textural variability. The percentage of the sediment texture that remains unexplained, $\left[100-\left(100 R^{2}\right)\right]$ must be solved by other variables influencing the studied phenomenon. We consider that the characteristics of sediments in the source area and their availability to be eroded by wind should be considered the predominant variables that explain the remaining percentage of the studied phenomenon. According to this, the mineralogy, availability, and textural characteristics of the source area influence $13 \%$ of the modern eolian sedimentology.

Assessing the supply control on the formation of fossil dunes is, however, difficult and even intractable. Increased late Miocene-Pliocene volcanism (Kay and Coira 2009, among others) is likely have to increased available sediment and supply of lightweight lithotypes. Consequently, in addition to the predominant control $(\sim 87 \%)$ of wind on the formation of eolian deposits, the nature and availability of sediments in the source area also highly influence the textural and mineralogical features of eolian 
deposits in the study system. The fact that the textural characteristics of eolian sands are partially dependent on the source area is further enhancing the role of the changing geological environment on controlling the formation of fossil and modern dunes.

The density of fossil eolian sands is determined by the presence of lightweight volcanic fragments. The incorporation of these sediments into fossil eolian sands results in lower bulk densities compared with modern deposits. The difference between the mean bulk densities of the fossil and modern eolian sands (1209 to $1611 \mathrm{~kg} / \mathrm{m}^{3}$, respectively), represents a variation of $33 \%$ that is not reflected in textural means (fossil $M=0.30$ and modern $M=0.29$, Table 5). Nonetheless, as noted in a previous section of this discussion, less dense grains are related to movement threshold values characterizing wind-speed conditions slower than present. Maximum wind speeds calculated based on $D_{\max }$ are $\sim 5 \%$ slower in the fossil system than today (e.g., $73 \mathrm{~km} / \mathrm{h}$ versus $77 \mathrm{~km} / \mathrm{h}$, for $\rho$ of 947 and $1560 \mathrm{~kg} / \mathrm{m}^{3}$, respectively, with $D_{\max }=1.68 \mathrm{~mm}$, Table 6). $D_{\max }$ in the fossil system could have been conditioned by a grain-size restriction associated with highly sorted sediments at the source region; the quantification of the maximum wind speed charactering the fossil dynamics remains then uncertain. A more reliable approach to assess fossil speed field may be via the textural resemblances between modern and the fossil dunes. Mean values of density and grain size of modern and fossil dunes (i.e., 0.29 and $0.30 \mathrm{~mm}$ and 1611 and $1209 \mathrm{~kg} / \mathrm{m}^{3}$, respectively) are correlated with $W_{\text {mean }}$ of 23 and $21 \mathrm{~km} / \mathrm{h}$, respectively, which implies a mean wind regime about $9 \%$ slower during the Miocene compared to modern conditions.

\section{CONCLUSIONS}

The climatological and geological environments are the two main variables conditioning the eolian system in the study region. The climatological environment is defined by the wind-related elements of the climate, including wind direction and speed. The geological environment is largely conditioned by the availability of suitably sized sediments, the mineralogy, and location of the source area.

The differences in mineralogy between fossil and modern dunes indicate important changes in the geological environment. Two main mechanisms of sediment supply were identified in the eolian system: i) the supply of biotite- and glass-shards-rich sediments, and ii) the sediment deflation over dry surfaces and stream channels. The latter is a local, permanent mechanism in the eolian system, while volcanic-related sediment supply processes dominated the dune formation during the Miocene, more likely in the late Miocene.

While wind largely determines the textural characteristics of eolian deposits, data revealed that the sediment sorting is also partially conditioned by the source area. The difference between the mean bulk densities of the fossil and modern eolian sands (1209 to $1611 \mathrm{~kg} / \mathrm{m}^{3}$, respectively), represents a variation of $33 \%$ that is not reflected in textural means (fossil $M=0.30$ and modern $M=0.29$ ). These mean values of density and grains size are correlated with fossil and modern mean wind speeds of 21 and $23 \mathrm{~km} / \mathrm{h}$, respectively. Therefore, differences in density and comparable size distributions may indicate weaker past winds.

\section{ACKNOWLEDGMENTS}

This study was supported by the PRH Red 101 ANPCyT of the Argentinean State and the National University of Jujuy. R.L. López Steinmetz thanks the grant E/B003 of the SECTER-UNJu. Lab facilities and field logistical support were provided by the Institute of Geology and Mining of Jujuy.

\section{REFERENCES}

Abril, E.G., And Amengual, R., 1999, Niveles de paleocosta de la laguna de Pozuelos y el salar de Jama, Puna jujeña: Congreso Geológico Argentino, Proceedings, v. 2, p. 23-26 (in Spanish).
Adelmann, D., And Görler, K., 1998, Basin development in the southern Puna: sedimentary record from the Salar de Antofalla area NW Argentina [Abstract]: Congreso Latinoamericano de Geologia, Proceedings, v. 1, p. 26-27 (in Spanish).

Alonso, R.N., 1986, Ocurrencia, posición estratigráfica y génesis de los depósitos de boratos de la Puna argentina [Ph.D. thesis]: Universidad Nacional de Salta, Salta, 196 p. (in Spanish).

Alonso, R.N., Jordan, T.E., TABbutt, K.T., and Vandervoort, D.S., 1991, Giant evaporite belts of the Neogene Central Andes: Geology, v. 19, p. 401-404

Alonso, R.N., Bookhagen, B., Carrapa, B., Coutand, I., Haschke, M., Hilley, G.E., Schoenbohm, L., Sobel, E.R., Strecker, M.R., Trauth, M.H., and Villanueva, A., 2006, Tectonics, climate, and landscape evolution of the southern central Andes: the Argentine Puna Plateau and adjacent regions between 22 and $30^{\circ} \mathrm{S}$, in Oncken, O., Chong, G., Franz, G., Giese, P., Götze, H.-J., Ramos, V.A., Strecker, M.R., and Wigger, P., eds., The Andes Active Subduction Orogeny: Berlin, Springer, p. 265-284.

Argollo, J., and Mourguiart, P., 2000, Late Quaternary climate history of the Bolivian Altiplano: Quaternary International, v. 72, p. 37-51.

Bagnold, R.A., 1941, The Physics of Blown Sands and Desert Dunes: London, Chapman and Hall, $102 \mathrm{p}$

BAGNOLD, R.A., 1954, Experiments on a gravity-free dispersion of large solid spheres in a Newtonian fluid under shear: Royal Society of London, Proceedings, v. 225, p. 49-63. Bailey, J.E., Self, S., Wooller, L.K., And Mouginis-Mark, P.J., 2007, Discrimination of fluvial and eolian features on large ignimbrite sheets around La Pacana Caldera, Chile, using Landsat and SRTM-derived DEM: Remote Sensing of Environment, v. 108, p. 24 41

BARRON, E.J., AND WASHINGTON, W.M., 1985, Warm Cretaceous climates: high atmospheric $\mathrm{CO}_{2}$ as a plausible mechanism, in Sundquist, E.T., and Broecker, W.S., eds., The Carbon Cycle and Atmospheric $\mathrm{CO}_{2}$ : Natural Variations Archean to Present: American Geophysical Union, Geophysical Monograph 32, p. 546-553

BianchI, A.R., 1981, Las precipitaciones en el noroeste argentino: Instituto Nacional de Tecnología Agropecuaria, Estación Experimental Regional Agropecuaria Salta, 380 p.

Bianchi, A.R., and Yañez, C.E., 1992, Las precipitaciones en el noroeste argentino: Instituto Nacional de Tecnología Agropecuaria, Estación Experimental Regional Agropecuaria Salta, $388 \mathrm{p}$.

Bianchi, A.R., AND YÁÑzz, C.E., 2005, Base de datos mensuales de precipitaciones del noroeste argentino: Instituto Nacional de Tecnología Agropecuaria, Estación Experimental Regional Agropecuaria Salta, $41 \mathrm{p}$.

Blard, P.H., Silvestre, F., Tripati, A.K., Claude, C., Causse, C., Coudrain, A., Condom, T., Seidel, J.L., Vimeux, F., Moreau, C., Dumoulin, J.P., and La I., 2011, Lake highstands on the Altiplano (Tropical Andes) contemporaneous with Heinrich 1 and the Younger Dryas: new insights from ${ }^{14} \mathrm{C}, \mathrm{U}-\mathrm{Th}$ dating and $\delta^{18} \mathrm{O}$ of carbonates: Quaternary Science Reviews, v. 30, p. 3973-3989.

Butrago, L.G., and Larran, M.T., 1994, El clima de la Provincia de Jujuy: Cátedra de Climatología y Fenología Agrícola, Facultad de Ciencias Agrarias, Universidad Nacional de Jujuy, $120 \mathrm{p}$

Carrapa, B., Adelmann, D., Hilley, G.E., Mortimer, E., Sobel, E.R., and Strecker, M.R., 2005 , Oligocene range uplift and development of plateau morphology in the southern central Andes: Tectonics, v. 24, p. 1-19.

Chong, G., 1988, The Cenozoic saline deposits of the Chilean Andes between $18^{\circ}$ and $27^{\circ}$ S, in Bahlburg, H., Breitkreuz, C., and Geise, P., eds., The Southern Central Andes: Berlin, Springer-Verlag, p. 137-151.

Coira, B., Mahlburg, K.S., Pérez, B., Woll, B., Hanning, M., and Flores, P., 1999, Magmatic sources and tectonic setting of Gondwana margin Ordovician magmas, northern Puna of Argentina and Chile, in Ramos, V., and Keppie, D., eds., LaurentiaGondwana Connection before Pangea: Geological Society of America, Special Publication 336, p. 145-170.

Cristiani, C.A., Del Moro, A., Matteini, M., Mazzuoli, R., and Omarini, R., 1999, The magmatism linked to the Jurassic-Cretaceous rift of NW Argentina: the Tusaquillas plutonic complex (Central Andes): Congreso Geológico Argentino, Proceedings, v. 2, p. 190-193 (in Spanish).

DÁvila, F.M., AND Astinı, R.A., 2003, Las eolianitas de la Sierra de Famatina (Argentina): interacción paleoclimática tectónica en el antepaís fragmentado andino central durante el Mioceno Medio?: Revista Geológica de Chile, v. 30, p. 187-204.

De SiLVA, S., 2010, The largest wind ripples on Earth: Comment: Geology, v. 38, e218.

De Silva, S., Bailey, J.E., Mandt, K.E., and Viramonte, J.M., 2010, Yardangs in terrestrial ignimbrites: synergistic remote and field observations on Earth with applications to Mars: Planetary and Space Sciences, v. 58, p. 459-471.

De Silva, S., Spagnuolo, M.G., Bridges, N.T., and Zimbelman, J.R., 2013, Gravel-mantled megaripples of the Argentinean Puna: a model for their origin and growth with implications for Mars: Geological Society of America, v. 125, p. 1912-1929.

Del Papa, C., Hongn, F., Powel, J., Payrola, P., Do Campo, M., Strecker, M.R. Petrinovic, I., Schmitt, A.K., and Pereyra, R., 2013a, Middle Eocene-Oligocene broken-foreland evolution in the Andean Calchaqui Valley, NW Argentina: insights from stratigraphic, structural and provenance studies: Basin Research, v. 25, p. 1-20.

Del Papa, C., Hongn, F., Payrola, P., Powel, J., Deraco, V., and Herrera, C., 2013b, Relaciones estratigráficas de las Formaciones Quebrada de los Colorados y Angastaco (Paleógeno-Neógeno), Valles Calchaquíes, Salta (Argentina): significado en el análisis 
de la cuenca del grupo Payogastilla: Latin American Journal of Sedimentology and Basin Analysis, v. 20, p. 51-64

Díaz, J.I., ANd MalizZia, D., 1983, Estudio geológico y sedimentológico del Terciario Superior del valle Calchaquí, Salta: Boletín Sedimentológico, v. 2, p. 8-28.

Flower, B.P., And KennetT, J.P., 1994, The middle Miocene climatic transition: East Antarctic ice sheet development, deep ocean circulation and global carbon cycling: Palaeogeography, Palaeoclimatology, Palaeoecology, v. 108, p. 537-555.

Fornari, M., Risacher, F., and Féraud, G., 2001, Dating of paleolakes in the central Altiplano of Bolivia: Palaeogeography, Palaeoclimatology, Palaeoecology, v. 172, p. 269-282.

Fritz, S.C., Baker, P.A., Lowenstein, T.K., Seltzer, G.O., Rigsby, C.A., Dwyer, G.S., TAPIA, P.M., ARnold, K.K., Ku, T.-L., AND Luo, S., 2004, Hydrologic variation during the past 170,000 years in the southern hemisphere tropics of South America: Quaternary Research, v. 61, p. 95-104.

Fritz, S.C., Baker, P.A., Seltzer, G.O., Ballantyne, A., Tapia, P., Cheng, H., and EDWARDS, R.L., 2007, Quaternary glaciation and hydrologic variation in the South American tropics as reconstructed from the Lake Titicaca drilling project: Quaternary Research, v. 68 , p. $410-420$

Galli, C.I., Coira, B., Alonso, R.N., Reynolds, J., Matteini, M., and Hauser, N., 2014, Tectonic controls on the evolution of the Andean Cenozoic foreland basin: evidence from fluvial system variations in the Payogastilla Group, in the Calchaquí, Tonco and Amblayo Valleys, NW Argentina: Journal of South American Earth Sciences, v. 52, p. 234-259.

GarREAUd, R.D., 2009, The Andes climate and weather: Advances in Geosciences, v. 22, p. $3-11$.

Gayo, E.M., Latorre, C., Jordan, T.E., Nester, P.L., Estay, S.A., Ojeda, K.F., and SANToro, C.M., 2012, Late Quaternary hydrological and ecological changes in the hyperarid core of the northern Atacama Desert $\left(\sim 21^{\circ} \mathrm{S}\right)$ : Earth-Science Reviews, v. 113 , p. $120-140$.

Greene, L.L., 1995, Eolian landforms in the central Andes: implications for the long-term stability of atmospheric circulation [M.S. thesis]: Cornell University, Ithaca, New York, $62 \mathrm{p}$.

Gregory-Wodzicki, K., 2000, Uplift history of the Central and Northern Andes: a review: Geological Society of America, Bulletin, v. 112, p. 1091-1105.

Hamon, N., Sepulchre, P., Lefevre, V., and Ramstein, G., 2013, The role of eastern Tethys seaway closure in the Middle Miocene Climatic Transition (ca. $14 \mathrm{Ma}$ ): Climate of the Past, v. 9, p. 2687-2702.

HartLEY, A.J., 2003, Andean uplift and climate change: Geological Society of London, Journal, v. 160 , p. 7-10.

Hartley, A.J., and Chong, G., 2002a, A late Pliocene age for the Atacama Desert: implications for the desertification of western South America: Geology, v. 30, p. 43-46. Hartley, A.J., And Chong, G., 2002b, Andean uplift and climate change: Geological Society of London, Journal, v. 160, p. 7-10.

Ehlers, J., and GibBard, P.L., 2007, The extent and chronology of Cenozoic Global Glaciation: Quaternary International, v. 164-165, p. 6-20.

IgarzÁBal, A.P., AND Rivelli, F.R., 1996, Características y evolución morfológica de la masa de arena de la depresión Salinas Grandes-Guayatayoc en la Puna jujeña: Instituto de Geología y Minería, Universidad Nacional de Jujuy, Revista, v. 11, p. 27-40.

InBAR, M., AND RISSO, C., 2001, Holocene yardangs in volcanic terrains in the southern Andes, Argentina: Earth Surface Processes and Landforms, v. 26, p. 657-666.

IsACKS, B.L., 1988, Uplift of the central Andes and bending of the Bolivian orocline: Journal of Geophysical Research, v. 93, p. 3211-3231.

KAY, S.M., AND COIRA, B., 2009, Shallowing and steepening subduction zones, continental lithospheric loss, magmatism, and crustal flow under the central Andean Altiplano-Puna Plateau, in Kay, S.M., Ramos, V.A., and Dickinson, W.R., eds., Backbone of the Americas: Plateau Uplift, Shallow Subduction, and Ridge Collision: Geological Society of America, Memoir 204, p. 229-259.

Kay, S.M., Colra, B., CAfFe, P.J., and Chen, C.-H., 2010, Regional chemical diversity, crustal and mantle sources and evolution of central Andean Puna plateau ignimbrites: Journal of Volcanology and Geothermal Research, v. 198, p. 81-111.

Kelly, P.M., and Sear, C.B., 1984, Climatic impact of explosive volcanic eruptions: Nature, v. 311, p. 740-743.

Kirschbaum, A., Hongn, F., and Menegatti, N., 2006, The Cobres Plutonic Complex, eastern Puna (NW Argentina): petrological and structural constraints for Lower Paleozoic magmatism: Journal of South American Earth Sciences, v. 21, p. 252-266.

Kraemer, B., Adelmann, D., Alten, M., Schnurr, W., Erpenstein, K., Kiefer, E., Van Der BogaArd, P., AND Görler, K., 1999, Incorporation of the Paleogene foreland into the Neogene Puna plateau: the Salar de Antofalla area, NW Argentina: Journal of South American Earth Sciences, v. 12, p. 157-182.

Lear, C.H., Bailey, T.R., Rearson, P.N., Coxall, H.K., and Rosenthal, Y., 2008, Cooling and ice growth across the Eocene-Oligocene transition: Geology, v. 36, p. 251-254.

López Steinmetz, R.L., 2013, Génesis y evolución de la Laguna de Guayatayoc, Puna jujeña, NW Argentina [Ph.D. thesis]: Universidad Nacional de Salta, Salta, 336 p. (in Spanish).

López SteinmetZ, R.L., AND Galli, C.I., 2015, Hydrological change during the PleistoceneHolocene transition associated to the Last Glacial Maximum-Altithermal in the eastern border of Northern Puna: Andean Geology, v. 42, p. 1-19.
MasLin, M., 2009, Quaternary climate transitions and cycles, in Gornitz, V., ed., Encyclopedia of Paleoclimatology and Ancient Environments: Dordrecht, Springer, Encyclopedia of Earth Sciences Series, p. 841-855.

McGlue, M.M., Cohen, A.S., Ellis, G.S., AND Kowler, A.L., 2013, Late Quaternary stratigraphy, sedimentology, and geochemistry of an underfilled lake basin in the Puna plateau (northwest Argentina): Basin Research, v. 59, p. 1237-1256.

Méndez, V., Navarini, A., Plaza, D., and Viera, O., 1973, Faja Eruptiva de la Puna oriental: Congreso Geológico Argentino, Proceedings, v. 4, p. 89-100 (in Spanish).

MilanA, J.P., 2009, Largest wind ripples on Earth?: Geology, v. 37, p. 343-346.

Milana, J.P., Forman, S., ANd KröHling, D., 2010, The largest wind ripples on earth [Reply]: Geology, v. 38, e219.

Miller, G.H., Mode, W.N., Wolfe, A.P., Sauer, P.E., Bennike, O., Forman, S.L., Short, S.K., AND STAFFord, T.W., JR., 1999, Stratified interglacial lacustrine sediments from Baffin Island, Arctic Canada: chronology and paleoenvironmental implications: Quaternary Science Reviews, v. 18, p. 789-810.

NAMIKAS, S.L., 2003, Field measurement and numerical modeling of aeolian mass flux distributions on a sandy beach: Sedimentology, v. 50, p. 303-326.

Paduano, G.M., Bush, M.B., Baker, P.A., Fritz, S.C., and Seltzer, G.O., 2003, A vegetation and fire history of Lake Titicaca since the Last Glacial Maximum: Palaeogeography, Palaeoclimatology, Palaeoecology, v. 194, p. 259-279.

Parrish, J.T., Ziegler, A.M., and Scotese, C.R., 1982, Rainfall patterns and the distribution of coals in the Mesozoic and Cenozoic: Palaeogeography, Palaeoclimatology, Palaeoecology, v. 40, p. 67-101.

Preusser, F., Detlev, D., Fuchs, M., Hilgers, A., Kadereit, A., Klasen, N., Krbetschek,

M., Richter, D., AND Spencer, J.Q.G., 2008, Luminiscence dating: basics, methods and applications: Quaternary Science Journal, v. 57, p. 95-149.

Quade, J., Rech, J.A., Betancourt, J.L., Latorre, C., Quade, B., Rylander, K.A., and Fisher, T., 2008, Paleowetlands and regional climate change in the central Atacama Desert, northern Chile: Quaternary Research, v. 69, p. 343-360.

Raymo, M.E., Ruddiman, W.F., and Froelich, P.N., 1988, Influence of late Cenozoic mountain building on ocean geochemical cycles: Geology, v. 16, p. 649-653.

RaYmo, M.E., Oppo, D.W., AND CURRY, W., 1997, The mid-Pleistocene climate transition: a deep-sea carbon isotopic perspective: Paleoceanography, v. 12, p. 546-559.

Rose, J., 2010, Quaternary climates: a perspective for global warming: The Geologists' Association, Proceedings, v. 121 , p. 334-341.

Seggiaro, R., 1994, Petrología, geoquímica y mecanismos de erupción del Complejo Volcánico Coranzulí [Ph.D. Thesis]: Universidad Nacional de Salta, Salta, 137 p. (in Spanish).

SegGiaro, R.E., And Aniel, B., 1989, Los ciclos piroclásticos del área Tiomayo-Coranzulí, Provincia de Jujuy: Revista de la Asociación Geológica Argentina, v. 44, p. 394-401 (in Spanish with English abstract).

Sherman, D.J., Li, B., Ellis, J.T., Farrel, E.J., Parente Maia, L., and Granja, H., 2013, Recalibrating eolian sand transport models: Earth Surface Processes and Landforms, v. 38, p. $169-178$.

Shevenell, A.E., Kennett, J.P., And Lea, D.W., 2008, Middle Miocene ice sheet dynamics, deep-sea temperatures and carbon cycling: a southern ocean perspective. Geochemistry Geophysics Geosystems, v. 9, doi:10.1029/2007GC001736.

Singhvi, A.K., Bluszcz, A., Bateman, M.D., and Rao, M.S., 2001, Luminescence dating of loess-palaeosol sequences and coversands: methodological aspects and palaeoclimatic implications: Earth-Science Reviews, v. 54, p. 193-211.

Soler, M.M., Caffe, P.J., Coira, B., Onoe, A.T., And Kay, S.M., 2007, Geology of the Vilama caldera: a new interpretation of a large-scale explosive event in the Central Andean plateau during the Upper Miocene: Journal of Volcanology and Geothermal Research, v. 164, p. $27-53$

Swingedoum, D., Mignot, J., Ortega, P., Khodri, M., Menegoz, M., Cassou, C., and Hanquiez, V., 2017, Impact of explosive volcanic eruptions on the main climate variability modes: Global and Planetary Change, v. 150, p. 24-45.

Sylvestre, M., Servant, M., Servant-Vildary, S., Causse, C., Fournier, M., and Ybert, J.P., 1999, Lake level chronology on the Southern Bolivian Altiplano $\left(18^{\circ}-23^{\circ} \mathrm{S}\right)$ during Late-Glacial Time and the Early Holocene: Quaternary Research, v. 51, p. 54-66.

Tapia, P.M., Fritz, S.C., Baker, P.A., Seltzer, G.O., and Dunbar, R.B., 2003, A Late Quaternary diatom record of tropical climatic history from Lake Titicaca (Perú and Bolivia): Palaeogeography, Palaeoclimatology, Palaeoecology, v. 194, p. 139-164

Turner, J.C., 1959, Estratigrafía del Cordón de Escaya y la Sierra de Rinconada, Jujuy: Revista de la Asociación Geológica Argentina, v. 15, p. 15-39 (in Spanish with English abstract).

TuRner, J.C., 1960a, Estratigrafía de la Sierra de Santa Victoria y adyacencias: Academia Nacional de Ciencias, Córdoba, Boletín, v. 41, p. 163-169.

TuRNer, J.C., 1960b, Estratigrafía del Nevado de Cachi y sector al oeste (Salta): Acta Geológica Lilloana, Tucumán, v. 3, p. 191-226.

Vandervoort, D., Jordan, T., Zeitler, P., And Alonso, R.N., 1995, Chronology of internal drainage development and uplift, southern Puna plateau, Argentina Central Andes: Geology, v. 23, p. 145-148.

Von Karman, T., 1934, Turbulence and skin friction: Journal of Aerosol Sciences, v. 1, p. $1-20$.

Voss, R., 2002, Cenozoic stratigraphy of the southern Salar de Antofalla region, northwestern Argentina: Revista Geológica de Chile, v. 29, p. 151-165. 
Wolfe, A.P., Fréchette, B., Richard, P.J.H., Miller, G.H., and Forman, S.L., 2000, Paleoecological assessment of a $>90,000$-year record from Fog Lake, Baffin Island, Arctic Canada: Quaternary Science Reviews, p. 1677-1699.

ZapetTinI, E., 1989, Geología y metalogénesis de la región comprendida entre las localidades de Santa Ana y Cobres, Provincias de Jujuy y Salta. República Argentina [Ph.D. thesis]: Universidad de Buenos Aires, Buenas Aires, 165 p. (in Spanish)

ZeCH, J., ZeCH, R., KUBIK, P.W., AND VEIT, H., 2009a, Glaciers and climate reconstruction at Tres Lagunas, NW Argentina, based on 10Be surface exposure dating and lake sediment analyses: Palaeogeography, Palaeoclimatology, Palaeoecology, v. 284, p. $180-190$.

Zech, R., Smith, J., and Kaplan, M.R., 2009b, Chronologies of the Last Glacial Maximum and its Termination in the Andes $\left(\sim 10-55^{\circ} \mathrm{S}\right)$ based on surface exposure dating, in Vimeux, F., Sylvestre, F., and Khodri, M., eds., Past Climate Variability in South
America and Surrounding Regions from the Last Glacial Maximum to the Holocene: Berlin, Springer, p. 61-88

ZINGG, A.W., 1953, Wind tunnel studies of movement of sedimentary material: Iowa City, University of Iowa, 5th Hydraulic Conference, Proceedings, v. 34, p. 111-134.

ZipPrich, M., ReIZner, B., Zech, W., AND Stingl, H., 1999, Upper Quaternary landscape and climate evolution in the Sierra de Santa Victoria (northwestern Argentina) deduced from geomorphologic and pedogenic evidence: Zentralblatt für Geologie und Paläontologie, v. 1, p. 997-1011.

Received 21 November 2016; accepted 15 November 2017 
Queries for sedp-88-01-05

This manuscript/text has been typeset from the submitted material. Please check this proof carefully to make sure there have been no font conversion errors or inadvertent formatting errors. Allen Press. 